\title{
The Property Rights Movement's Embrace of Intellectual Property: True Love or Doomed Relationship?
}

\author{
Peter S. Menell
}

Introduction 713

I. Cross-Currents in Real and Intellectual Property .........................719

A. Law and Legal Classifications ..................................................719

B. Theoretical Underpinnings of Real and Intellectual Property

II. eBay v. MercExchange. An Inauspicious First Date .....................731

A. The Rise of Business Method Patents......................................731

B. The MercExchange Patents and the Enforcement Proceedings

C. The Supreme Court Battle and the PRM's Embrace of Intellectual Property .................................................................. 737

D. Post-Mortem: A Disappointing First Date ..............................739

III. Sources of Tension in the PRM-IP Relationship ............................741

A. Philosophical and Religious Differences ……….....................742

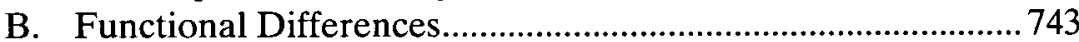

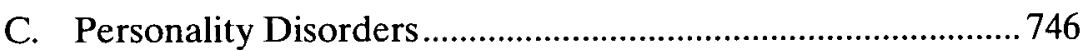

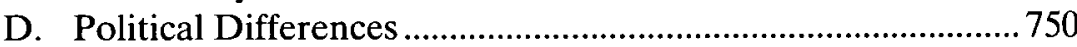

IV. Implications of the Rise of Intellectual Property for the Protection of Real Property ............................................................ 751

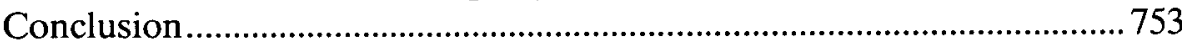

\section{INTRODUCTION}

The Property Rights Movement (PRM) ${ }^{1}$ took active interest in several cases argued during the past several Supreme Court terms. It was

Copyright $\odot 2007$ by the Regents of the University of California.

Professor of Law and Director, Berkeley Center for Law \& Technology, University of California, Berkeley, School of Law. I am grateful to Michael Carroll, Justin Hughes, Mark Lemley, and Rob Merges for comments, and to Tom Fletcher and Jayni Foley for research assistance.

1. See generally Douglas T. Kendall \& Charles P. Lord, The Takings Project: A Critical Analysis and Assessment of the Progress So Far, 25 B.C. ENVTL. AFF. L. REV. 509 (1998). 
hardly surprising to see PRM activists mobilize in support of Susette Kelo, whose home was condemned by the city of New London to make way for Pfizer Corporation to clear the land for construction of an industrial park. ${ }^{2}$ Ms. Kelo's plight fell squarely within PRM's core agenda of safeguarding the liberty interests of property owners against governmental interference. ${ }^{3}$ Ms. Kelo objected to the condemnation, asserting her right under the Fifth Amendment to the U.S. Constitution not to have her property taken unless for "public use." She argued that condemning her property to convey it to a private developer did not constitute "public use" and hence violated her constitutional rights. Images of Ms. Kelo and her middle class home made front-page news throughout the nation. ${ }^{5}$ The property at issue, as well as the government's exercise of power, could not have been more tangible and transparent. Nor was it surprising to see PRM organizations file briefs in Rapanos $v$. United States, ${ }^{6}$ involving the scope of federal authority to regulate wetlands; San Remo Hotel v. City \& County of San Francisco, ${ }^{7}$ challenging the constitutionality of a hotel conversion ordinance under the Takings Clause; Lingle v. Chevron U.S.A., ${ }^{8}$ seeking to overturn a state statute limiting the rent that oil companies could charge dealers leasing company-owned service stations; or Tahoe-Sierra Preservation Council, Inc. v. Tahoe Regional Planning Agency, ${ }^{9}$ asserting that a temporary moratorium on development effected an unconstitutional taking of private property.

By contrast, the case of eBay $v$. MercExchange did not seem to fit the PRM profile. The "property" at issue-a patent on a method of

2. See Kelo v. City of New London, 545 U.S. 469 (2005).

3. Among the prominent PRM groups that filed briefs in support of Kelo's position were: the Reason Foundation, the Property Rights Foundation of America, Mountain States Legal Foundation, Defenders of Property Rights, Pacific Legal Foundation, Center for Individual Freedom, and the Cato Institute. These groups share a common interest in promoting individual liberties, the right to own and use property, limited government, and the free enterprise system.

4. U.S. CONST. amend. V.

5. See, e.g., Linda Greenhouse, Justices Uphold Taking Property for Development, N.Y. TimES, June 24, 2005, at A1; Kirstin Downey, Revitalization Projects Hinge on Eminent-Domain Lawsuit, WASH. POST, May 21, 2005, at E1.

6. 126 S. Ct. 2208 (2006). PRM organizations participating in Rapanos v. United States included the Cato Institute, Washington Legal Foundation, and Mountain States Legal Foundation.

7. 545 U.S. 323 (2005). PRM organizations participating in San Remo Hotel v. City \& County of San Francisco included Defenders of Property Rights, Pacific Legal Foundation, the Washington Legal Foundation, and Property Rights Foundation of America.

8. 544 U.S. 528 (2005). PRM organizations participating in Lingle v. Chevron U.S.A. included the Cato Institute, the Pacific Legal Foundation, and Defenders of Property Rights.

9. 535 U.S. 302 (2002). PRM organizations participating in Tahoe-Sierra Preservation Council, Inc. v. Tahoe Regional Planning Agency included Washington Legal Foundation, Defenders of Property Rights, Institute for Justice, and Pacific Legal Foundation. 
selling goods through an "electronic network of consignment stores"10 could hardly have been more different in its nature and economic underpinning than Susette Kelo's home. MercExchange, the owner of the patent, did not itself practice the invention but instead focused upon enforcement and licensing. MercExchange had prevailed in a patent infringement action and next sought to enjoin eBay, the popular online auctioneer, from further use of the patented method..$^{11}$ The patentability of such methods was itself quite controversial due to (1) the recent expansion of patentable subject matter to encompass business methods, ${ }^{12}$ (2) the difficulty of searching prior $\operatorname{art}^{13}$ in such fields, (3) the challenge of determining obviousness of such inventions, and (4) questions about the adequacy of disclosure. ${ }^{14}$ Furthermore, the governmental "interference" with the patent owner's property was limited to a court's exercise of discretion to award damages instead of a permanent injunction for reasons based on the patent owner's willingness to license to other parties, the fact that the patentee did not itself practice the invention, and "growing concern" over effects of business method patents. ${ }^{15}$ The U.S. Court of Appeals for the Federal Circuit overturned the denial of the permanent injunction, holding that as a "general rule" injunctions must follow all patent infringement findings unless "exceptional circumstances," such as a grave risk to public health, would result. ${ }^{16}$ eBay appealed to the Supreme Court, which granted certiorari in late 2005.

In an amicus brief filed in the Supreme Court on behalf of "various law and economics scholars," ${ }^{, 17}$ Professor Richard Epstein, PRM's leading

10. U.S. Patent No. 5,845,265 (filed Dec. 1, 1998).

11. See eBay Inc. v. MercExchange, L.L.C., 126 S. Ct. 1837 (2006).

12. For most of the twentieth century, courts and most commentators considered business methods to be unpatentable. In 1998, the Federal Circuit laid "to rest" what it called the "illconceived business method exception." See State Street Bank \& Trust Co. v. Signature Fin. Group, Inc., 149 F.3d 1368, 1375 (Fed. Cir. 1998), cert. denied, 525 U.S. 1093 (1999).

13. "Prior art" generally refers to publications, patents, and other sources available before an invention is made that discloses the invention.

14. See U.S. Fed. Trade Comm'n, To Promote Innovation: The Proper Balance OF COMPETITION AND PATENT LAW AND POLICY ch. 3 (2003) [hereinafter FTC REPORT]; Rochelle Cooper Dreyfuss, Are Business Method Patents Bad for Business?, 16 SanTa ClaRA Computer \& High TeCH. L.J. 263 (2000); Michael J. Meurer \& Robert P. Merges, As Many as Six Impossible Patents Before Breakfast: Property Rights for Business Concepts and Patent System Reform, 14 BERKELEY TECH. L.J. 577 (1999); Michael J. Meurer, Business Methods and Patent Floods, 8 WASH. U. J.L. \& POL'Y 309, 335-36 (2002); Michael J. Meurer, Controlling Opportunistic and Anti-Competitive Intellectual Property Litigation, 44 B.C. L. REV. 509, 541 (2003); cf. John R. Thomas, The Patenting of the Liberal Professions, 40 B.C. L. REV. 1139, 1176 (1999).

15. MercExchange, L.L.C. v. eBay, Inc., 275 F. Supp. 2d 695, 711-15 (E.D. Va. 2003), aff'd in part and rev'd in part, $401 \mathrm{~F} .3 \mathrm{~d} 1323$ (Fed. Cir. 2005), vacated, $126 \mathrm{~S}$. Ct. 1837 (2006).

16. MercExchange, 401 F.3d at 1338-39.

17. See Brief for Various Law \& Economics Professors as Amici Curiae in support of Respondent, eBay, 126 S. Ct. 1837 (No. 05-130), 2006 WL 639164 [hereinafter Epstein Brief]. 
theorist, ${ }^{18}$ along with libertarian-leaning colleagues, ${ }^{19}$ contended that the MercExchange patent deserves much the same protection as real estate. ${ }^{20}$ By analogizing patent protection to trespass law, the brief argued that injunctive relief should be presumed in cases of patent infringement. It pushed the boundaries of patent law advocacy by citing land encroachment precedent. $^{21}$

The eBay case and the property rights rhetoric surrounding it marked an important new front in the campaign to establish a strict and broad interpretation of property rights and their enforcement. Professor Epstein's expansion of his property rights advocacy into the intellectual property domain over the past several years ${ }^{22}$ coincides with the growing importance of intangible assets in the modern economy. The digital revolution has displaced General Motors and other manufacturing enterprises from the top of the economic food chain. Knowledge-based companies such as Google, Microsoft, and Apple reflect the new

18. Professor Epstein is widely viewed as one, if not the chief, intellectual architect of the movement to use the Takings Clause of the Fifth Amendment to strengthen the rights of private property owners and scale back governmental regulation of property and business. His 1983 book, Takings, Private Property and the Power of Eminent Domain, has been characterized as the blueprint for the PRM. See generally Kendall \& Lord, supra note 1, at 510.

19. The other authors of the brief were F. Scott Kieff, a professor of intellectual property law and law and economics at Washington University School of Law, and R. Polk Wagner, a professor specializing in intellectual property law at the University of Pennsylvania Law School. Both have advocated strong protection of intellectual property rights. See, e.g., F. Scott Kieff, Property Rights and Property Rules for Commercializing Inventions, 85 MINN. L. REV. 697 (2001); R. Polk Wagner, Information Wants to Be Free: Intellectual Property and the Mythologies of Control, 103 ColuM. L. REV. 995 (2003).

20. Some other briefs referenced real property law. See, e.g., Brief for American Intellectual Property Law Association and Federal Circuit Bar Association as Amici Curiae in Support of Neither Party at 15, eBay v. MercExchange, 126 S. Ct. 1837 (2006) (No. 05-130), 2006 WL 148639 , at *15 (observing that "[r]eal property cases have long considered the balance of the hardships to the property owner and the party accused of trespass, encroachment or nuisance"), but did not take nearly as dogmatic a view as the Epstein Brief on the crucial issue of exclusivity of property rights, id. at 17 (citing Michael A. Carrier, Cabining Intellectual Property Through a Property Paradigm, 54 DUKE L.J. 1, 73-74 (2004) (urging application of equitable limitations on real property enforcement to intellectual property)).

21. See Epstein Brief, supra note 17, at 16-17.

22. See Richard A. Epstein, Keynote Address at the Aspen Summit: The Structural Unity of Real and Intellectual Property (Aug. 21, 2006) (The Progress \& Freedom Foundation), available at http://www.pff.org/issues-pubs/pops/pop13.24RAE_9_26.pdf [hereinafter Epstein, Structural Unity]; Richard A. Epstein, Intellectual Property: Top Down and Bottom Up, in CAPITAL FOR OUR TIME 85 (Nicholas Imparato ed. 1998); Richard A. Epstein, Steady the Course: Property Rights in Genetic Material, in PERSPECTIVES ON PROPERTIES OF THE HUMAN GENOME ProjeCT 153 (F. Scott Kieff ed., 2003); Richard A. Epstein, Intellectual Property: Old Boundaries and New Frontiers, 76 IND. L.J. 803 (2001); Richard A. Epstein, Liberty Versus Property? Cracks in the Foundations of Copyright Law, 42 SAN DIEGO L. REV. 1 (2005); Richard A. Epstein, Property Rights in cDNA Sequences: A New Resident for the Public Domain, 3 U. Chi. L. Sch. Roundtable 575 (1996); Richard A. Epstein, Respect Bayer's Patent: Cheap Cipro Now Could Cost Us Dearly in the Long Run, WALL ST. J., Oct. 25, 2001. 
economic order. ${ }^{23}$ It remains to be seen whether Epstein's libertarian framework can be successfully "ported" to this new economic platform.

MercExchange and several other intellectual property owners favoring a strong presumption of injunctive relief for patent infringement $^{24}$ were no doubt glad to have support from such a wellknown conventional property rights advocate. The involvement of Professor Epstein could be expected to attract the notice of Justices Scalia and Thomas, ardent supporters of property rights. ${ }^{25}$ It might also catch the attention of the most recent appointments to the Court. Both Chief Justice Roberts and Justice Alito have connections to the conservative Federalist Society ${ }^{26}$ which has long been associated with the PRM. ${ }^{27}$ The oral argument in the case seemed to bear out this strategic linkage when Justice Scalia remarked: "[W]e're talking about a property right here and the property right is explicitly the right to exclude others from use of that. That's what a patent right is. And all he's asking for is give me my property back."28

The PRM's (or at least one of its intellectual leaders) embrace of intellectual property, however, masks important philosophical, functional, intellectual, and political tensions. The PRM rests on an unyielding belief in both natural rights theory and libertarian philosophy whereas intellectual property owners, scholars, and policy analysts tend to be far less dogmatic. Their support for property rights reflects a

23. Cf. Steve Lohr, Microsoft and Google Grapple for Supremacy as Stakes Escalate, N.Y. TimES, May 10, 2006, at C1 (reflecting the ascendancy of digital technology companies in the economy).

24. Among the groups supporting MercExchange were the pharmaceutical industry, the biotechnology industry, and several large broad-based technology companies. Several other intellectual property owners and organizations, principally associated with the information technology sector, weighed in on the side of eBay. See infra text accompanying notes 130-132.

25. See Lucas v. S.C. Coastal Council, 505 U.S. 1003, 1027 (1992) ("Where the State seeks to sustain regulation that deprives land of all economically beneficial use, we think it may resist compensation only if the logically antecedent inquiry into the nature of the owner's estate shows that the proscribed use interests were not part of his title to begin with."); Kelo v. City of New London, 545 U.S. 469, 505 (2005) (Thomas, J., dissenting) ("Long ago, William Blackstone wrote that "the law of the land ... postpone[s] even public necessity to the sacred and inviolable rights of private property."'(modification in original)); id. at 508 ("The most natural reading of the [Takings] Clause is that it allows the government to take property only if the government owns, or the public has a legal right to use, the property, as opposed to taking it for any public purpose or necessity whatsoever.")

26. See Charles Lane, Roberts Listed in Federalist Society '97-98 Directory: Court Nominee Said He Has No Memory of Membership, WASH. POST, July 25, 2005, at A1; David Montgomery, No Secrets Here: Federalist Society Plots In the Open-Conservative Legal Group Focuses on Judiciary to Come, WASH. POST, Nov. 18, 2006, at C1 (noting that Justice Samuel Alito is a longtime Federalist Society member).

27. See Federalist Society, http://www.fed-soc.org/aboutus/. The Federalist Society has an "Environmental Law and Property Rights Practice Group. See Federalist Society Practice Group Leadership Directory, http://www.fed-soc.org/browseby_practice_group.asp.

28. Transcript of Oral Argument at 4, eBay, Inc. v. MercExchange, L.L.C., 126 S. Ct. 1837 (2006) (No. 05-130), available at 2006 U.S. Trans Lexis 29, at*4. 
mixture of natural rights and utilitarian precepts. ${ }^{29}$ And they tend to be far more pragmatic than PRM stalwarts. By trying to use the intellectual property sphere to call attention to the erosion of private property rights, the PRM may actually have the opposite effect-as reflected in the outcome of eBay v. MercExchange. In a unanimous decision authored by Justice Thomas, the Court ruled that injunctions should not be presumed in patent cases; rather courts should exercise equitable discretion in determining relief. $^{30}$ Chief Justice Roberts's concurrence, joined by Justices Scalia and Ginsburg, no doubt gave the PRM some solace by noting that the "long tradition of equity practice" of granting injunctive relief in the vast majority of patent cases upon a finding of infringement reflects "the difficulty of protecting a right to exclude through monetary remedies that allow an infringer to use an invention against the patentee's wishes." 31 But Justice Kennedy, in a concurrence joined by Justices Stevens, Souter, and Breyer, offered a more nuanced and flexible approach toward the exercise of discretion in enforcing intellectual property rights by emphasizing the particular characteristics of business method patents. ${ }^{32}$ Only time will tell how strongly patent rights will be enforced, although early indications suggest that a shift away from nearautomatic issuance of injunctions in patent cases is underway. ${ }^{33}$

This Article explores whether Professor Epstein's embrace of intellectual property rights is likely to produce a durable marriage of traditional property rights theory and intellectual property protection, or merely represents a fling that will not withstand divisive relational pressures. Part I provides historical background on the cross-currents between traditional property rights and intellectual property rights, revealing that the critical question is not whether intellectual property is a form of property but instead, what are the ramifications of such classification for the enforcement of intellectual property rights. Should they be treated as inviolate, and therefore enforced only by a property rule, or should courts apply equitable principles in determining the means of enforcement by either a property rule or a liability rule (an award of damages) ${ }^{34}$ Part II examines the rise of business method patents, MercExchange's efforts to enjoin eBay's use of its "technology,"

29. See infra text accompanying notes $62-66$.

30. See eBay, 126 S. Ct. 1837; see also 35 U.S.C. $\$ 283$ (2006) (a court may grant an injunction in a patent case "in accordance with the principles of equity to prevent the violation of any right secured by patent, on such terms as the court deems reasonable").

31. eBay, $126 \mathrm{~S}$. Ct. at 1841 (emphasis in original omitted).

32. See id. at 1842 .

33. See cases cited infra note 143 .

34. This Article employs the classic analytical distinction between property rules (rights enforced through injunctions) and liability rules (rights enforced through court-awarded damage awards). See Guido Calabresi \& A. Douglas Melamed, Property Rules, Liability Rules, and Inalienability: One View of the Cathedral, 85 HARV. L. REv. 1089 (1972). 
Professor Epstein's overreaching and misleading analogy to land trespass law, and the Supreme Court's interpretation of the injunctive relief standard in patent cases. Based on the characteristics of the PRM and intellectual property owners, Part III demonstrates that the relationship between traditional property rights advocates and intellectual property owners is likely to prove rather fragile. Strong philosophical, functional, personality, and political differences between these two constituencies raise serious doubts as to the viability of a property rights/intellectual property rights relationship. Although it seems likely that the two will date from time to time, the prospects for a harmonious, monogamous relationship seem doubtful. As Part IV suggests, the need for dynamism and adaptability within the intellectual property rights field may well weaken the support for absolutism in property jurisprudence and policy, reinforcing the shift away from the Blackstonian conception of property.

\section{CROSS-CURRENTS IN REAL AND INTELLECTUAL PROPERTY}

The philosophical, jurisprudential, and intellectual understandings of real and intellectual property are detailed and complex. Private property in land and other tangible resources is perhaps the oldest human institution and has long occupied a prominent position in law and philosophy. But to what extent does intellectual property-property in intangible resources - fall within the relatively uniform right structures applied to tangible resources? The focus here is on the nature and extent to which the concepts of real and intellectual property are intertwined. As Section A explains, the law has long treated real and intellectual property within the general rubric of "property." Professor Epstein asserts that the rules associated with real property (such as a strict right to exclude and restrictions on governmental interference) should govern intellectual property. Yet such a classification may have little analytical or substantive significance if the two fields are subject to significantly different rules and institutions. Section B explores the philosophical and intellectual history of the relationship between real and intellectual property.

\section{A. Law and Legal Classifications}

Land and other tangible resources have played a central role in human civilization throughout history. The concept of private propertyreflecting notions of exclusivity and transferability - is well established and has been justified by theories of natural rights, personhood, and utilitarianism..$^{35}$ In the extreme, Blackstone famously characterized

35. See generally John P. DWYer \& PETER S. MENELl, Property LAW AND Policy: A COMPARATIVE INSTITUTIONAL PERSPECTIVE (1998). 
property as "that sole and despotic dominion which one man claims and exercises over the external things of the world, in total exclusion of the right of any other individual in the universe"; "postpon[ing] even public necessity to the sacred and inviolable rights of private property." 36 Although this characterization of property protection as rigid, exclusive, and absolute is exaggerated, ${ }^{37}$ it nonetheless captures key attributes of property protection as well as the libertarian ideal of a just society.

Notwithstanding observations by several scholars that the term "intellectual property" originated recently, ${ }^{38}$ the courts and legislatures have long considered patents, copyrights, and trademarks to be "property" and have characterized them as such. ${ }^{39}$ Copyright has been referred to as a form of "property" or "literary property" since its inception in the early eighteenth century. ${ }^{40}$ The first use of the term "intellectual property" in a reported decision can be traced to an 1845 patent case where the court observed that "a liberal construction... given to a patent" will encourage "ingenuity and perseverance" and "only in this way can we protect intellectual property, the labors of the mind, productions and interests as much a man's own, and as much the fruit of his honest industry, as the wheat he cultivates, or the flocks he rears." Justin Hughes notes that "the courts and legislatures had regularly discussed copyrighted works as 'property' throughout the seventeenth, eighteenth, and early nineteenth centuries, with the adjectival concepts of

36. 2 WILLIAM BLACKSTONE, COMMENTARIES ON THE LAWS OF ENGLAND 2 (1765); 1 WILLIAM BLACKSTONE, COMMENTARIES ON THE LAWS OF ENGLAND 135 (1765), available at http://www.yale.edu/lawweb/avalon/blackstone/blacksto.htm.

37. See generally Carol M. Rose, Crystals and Mud in Property Law, 40 STAN. L. REV. 577 (1988) (exposing the muddiness of many property doctrines); Carrier, supra note 20, at 52-82 (cataloging doctrinal limits on absoluteness of property rights).

38. See Siva VAIDhyanathan, Copyrights and Copywrongs: The Rise of Intellectual Property and How IT Threatens Creativity 11 (2001) (suggesting that the term "intellectual property" is "fairly young"); Mark A. Lemley, Property, Intellectual Property, and Free Riding, 83 TEX. L. REV. 1031, 1031 (2005) ("Patent and copyright law have been around in the United States since its origin, but only recently has the term intellectual property' come into vogue.").

39. Justin Hughes, Copyright and Incomplete Historiographies: Of Piracy, Propertization, and Thomas Jefferson, 79 S. CAL. L. REV. 993 (2006).

40. British booksellers used property analogies drawn from Locke to support passage of the Statute of Anne. See generally Mark Rose, Copyright and Its Metaphors, 50 UCLA L. REV. 1, 7-8 (2002); Dane S. Ciolino \& Erin A. Donelon, Questioning Strict Liability in Copyright, 54 Rutgers L. REV. 351, 366 (2002). The term "literary property" appears in eighteenth-century statutes and cases. See Hughes, supra note 39, at 1014-42. The U.S. Supreme Court used the phrase "literary property" in International News Service v. Associated Press, 248 U.S. 215, 233 (1918). In fact, the Irish King Diarmed used the tangible property analogy in $567 \mathrm{CE}$ in ruling that a student had infringed his teacher's psalm book: "To every cow her calf, and accordingly to every book its copy." See Laurie Stearns, Comment, Copy Wrong: Plagiarism, Process, Property, and the Law, 80 CAL. L. REV. 513, 535-36 (1992) (observing that the "development of copyright law in England and the United States has built upon this notion that the relationship between authors and their writings is that of owners to their property").

41. Davoll v. Brown, 7 F. Cas. 197, 199 (C.C.D. Mass. 1845) (No. 3662) (emphasis added). 
'artistic,' 'literary,' and 'intellectual' orbiting around the property notion." ${ }^{42}$ An 1878 book defending the patent system was given the title Thoughts on the Nature of Intellectual Property and Its Importance to the States. ${ }^{43}$ Drone entitled his influential copyright treatise dating to 1879 A Treatise on the Law of Property in Intellectual Productions. ${ }^{44}$

There can be little question today that intellectual property assets are forms of "property." 45 The Patent Act expressly declares that "patents shall have the attributes of personal property"46 and the Supreme Court acknowledges them as such. ${ }^{47}$ The Copyright Act states that "ownership of a copyright may be transferred in whole or in part by any means of conveyance or by operation of law, and may be bequeathed by will or pass as personal property by the applicable laws of intestate succession." $\$ 48$ But the classification of patents, copyrights, trademarks, and trade secrets as forms of "property" does not resolve the contours of these assets and the rights and protections that their owners enjoy. Property is not a monolithic concept and its treatment varies significantly across classes of resources. ${ }^{49}$ The critical question is not whether the rubric "property" applies to intellectual property but whether the traditional rights associated with real and other tangible forms of property apply to intellectual property.

To Professor Epstein and some other PRM advocates, ${ }^{50}$ the upshot of the "property" classification is that it would imbue intellectual property with the classic protections generally afforded land-such as strict exclusivity, enforcement via injunctive relief, and protection against government takings. These scholars would shoehorn intellectual property

42. See Hughes, supra note 39 , at 1006 .

43. See S. Shaler, ThoughtS ON THE Nature of INTEllectual Property AND ITS IMPORTANCE TO THE STATE (Boston, J.R. Osgood \& Co. 1878), cited in BRUCE W. BugBEE, GENESIS OF AMERICAN PATENT AND COPYRIGHT LAW 3-4 (1967).

44. Eaton S. Drone, A Treatise on the law of Property in Intellectual Productions in Great Britain and the United States $54-67$ (Boston, Little Brown 1879).

45. See, e.g., Ruckelshaus v. Monsanto Co, 467 U.S. 986 (1984) (trade secrets); In re World Auxiliary Power Co., 303 F.3d 1120, 1127, 1127 n.33 (9th Cir. 2002) (noting that Article 9 of the Uniform Commercial Code treats copyrights, trademarks, and patents as "general intangibles," "miscellaneous types of contractual rights and other personal property"); Krebs ChryslerPlymouth, Inc. v. Valley Motors, Inc., 141 F.3d 490, 497-98 (3d Cir. 1998) (observing that "[t]rademarks are property" and that "[t]he ownership of a trade-mark has, in general, been considered as a right of property" under Pennsylvania law).

46. 35 U.S.C. $\$ 261(2006)$.

47. See Festo Corp. v. Shoketsu Kinzoku Kogyo Kabishiki Co., 535 U.S. 722, 720, 739 (2002) (a patent "is a property right"; patent rights constitute "the legitimate expectations of inventors in their property"); Fla. Prepaid Postsecondary Educ. Expense Bd. v. College Savings Bank, 527 U.S. 627, 642 (1999) ("Patents ... have long been considered a species of property.").

48. See 17 U.S.C. $\$ 201$ (d) (2006) (emphasis added).

49. See DWYER \& MENELL, supra note 35.

50. See Frank H. Easterbrook, Intellectual Property Is Still Property, 13 HARV. J.L. \& PUB. POL'Y 108 (1990). 
into an idealized Blackstonian conception of property rights as exclusive and inviolate.

But there is another view that "property" is merely a general label that applies to a wide range of resources and assets with varying associated rights. The rights that attach to particular subclasses of assets, especially the modalities of intellectual property, vary considerably and should not be straitjacketed. Patents and copyrights, as instruments to promote progress in science and the arts, must be flexible and responsive to changes in technology, economic considerations, and public policy. The contours of intellectual property modes support this view in various ways. Copyright law's fair use doctrine, originality standard, numerous compulsory licenses, and various exemptions significantly qualify the exclusivity of copyright interests. ${ }^{51}$ Patent law's nonobviousness standard (merely being first is not enough, as it is in the case of the Homestead Act or mining law), experimental use defense, and various exceptions (e.g., limitations on enforcement of medical procedure patents, prior user rights for business methods) limit the exclusivity of patent rights. ${ }^{52}$ Trademark law's distinctiveness standard, infringement standard, and nominative use defense significantly constrain the exclusivity of trademark rights. ${ }^{53}$ Trade secret law's independent discovery defense similarly qualifies the exclusivity of such rights. ${ }^{54}$

Nonetheless, classification of intellectual property as "property" has substantive effect in some contexts. The Fifth Amendment limitations on takings of private property - requiring that private property not be taken without "due process"; limiting expropriations to "public use"; and requiring the payment of "just compensation"-turn on the classification. ${ }^{55}$ Thus, intellectual property receives treatment comparable to real and other forms of property. The Supreme Court has expressly held that trade secrets fall within this protection. ${ }^{56}$ Similarly, it is generally recognized that copyright protection cannot be contracted retroactively without raising due process and takings concerns. ${ }^{57}$ Interesting!y, scholars

51. See Robert P. Merges, Peter S. Menell \& Mark A. Lemley, intellectual PROPERTY IN THE NEW TECHNOLOGICAL AGE 376-86, 395-420, 498-502, 506-50 (4th ed. 2006) [hereinafter IPNTA].

52. See id. at $214-38,308-12 ; 35$ U.S.C. $\$ \S 273,287$ (c) (2006).

53. See id. at 634-60, 811-12.

54. See id. at 74-79.

55. See DWYER \& MENELL, supra note 35, at 318-25.

56. See Ruckelshaus v. Monsanto Co, 467 U.S. 986 (1984) (holding that trade secrets in data relevant for regulatory approval was cognizable as property subject to the protections of the Takings Clause of the Fifth Amendment); Phillip Morris, Inc. v. Reilly, 312 F.3d 24 (1st Cir. 2002) (holding that a state statute that would have required disclosure of trade secretsconstituent ingredients of tobacco products - constituted a regulatory taking).

57. See generally MElville B. Nimmer \& DAVID NimMER, NimMER ON COPYRIGHT \& 1.11 (Constitutiónal Limitations on Retroactivity and "Taking"). Although no court has yet addressed whether or how the Fifth Amendment's protections would be applied to retroactive 
and courts today consider the treatment of patents as "private property" for purposes of the Takings Clause to be novel and unclear. ${ }^{58}$ Yet Professor Adam Mossoff has unearthed a trove of nineteenth-century cases $^{59}$ suggesting that early jurists understood patents to be constitutional "private property" subject to the protections of the Takings Clause. ${ }^{60}$ As he notes, however, several late-nineteenth-century cases muddied this proposition by raising doubts as to whether any federal court is authorized to consider a takings claim by a patent owner. ${ }^{61}$ The eBay case addresses whether the "property" label carries much significance in determining the standard for injunctive relief.

\section{B. Theoretical Underpinnings of Real and Intellectual Property}

The PRM grounds its approach to property in John Locke's natural rights theory. ${ }^{62}$ Locke believed that every man had an inherent property

changes in copyright law, Congress chose not to make the Computer Software Rental Amendments Act of 1990 retroactive so as to avoid depriving software owners of vested rights without compensation. See H.R. REP. No. 101-735 (1990); cf. Laurence H. Tribe, Memorandum of Constitutional Law on Copyright Compensation Issues Raised by the Proposed Reversal of the Ninth Circuit's Betamax Ruling (Dec. 5, 1981), reprinted in A Bill to Amend Title 17 of the United States Code to Exempt the Private Noncommercial Recording of Copyrighted Works on Video Recorders from Copyright Infringement, Hearings on S. 1758 Before the S. Comm. on the Judiciary, 97th Cong., 1st \& 2d Sess., 78-154 (Nov. 30, 1981 \& Apr. 21, 1982), available at http://lawlibrary.rutgers.edu/cgi-bin/lib/hearing.cgi?file $=82603652 \% 20$ page $=0001$.

58. See, e.g., Zoltek Corp. v. United States, 442 F.3d 1345 (Fed. Cir. 2006); Da Graffenreid v. United States, 29 Fed. Cl. 384, 386-89 (1998); DAVID A. DANA \& ThOMAS W. MERRILL, PROPERTY: TAKINGS 233 (2002); Thomas F. Cotter, Do Federal Uses of Intellectual Property Implicate the Fifth Amendment?, 50 FLA. L. REV. 529 (1998).

59. See United States v. Burns, 79 U.S. (12 Wall.) 246 (1870) (holding that the Court of Claims, established in 1855 to adjudicate claims by citizens against the government for breach of contract and property rights, properly had jurisdiction over a claim by a patentee for the government's unauthorized use of his claimed invention); McClurg v. Kingsland, 42 U.S. (1 How.) 202, 206 (1843) (observing that a repeal of a patent statute "can have no effect to impair the right of property then existing in a patentee."); McKeever v. United States, 14 Ct. Cl. 396 (1878); Campbell v. James, 4 F. Cas. 1168, 1172 (C.C.S.D.N.Y. 1879) (No. 2361) (declaring that a patent, "like all other private property recognized by law, is exempt from being taken for public use without just compensation, by the supreme law of the land") rev'd on other grounds, James v. Campbell, 104 U.S. 356 (1881) (declaring patent invalid); cf. Cammeyer v. Newton, 94 U.S. (4 Otto) 225, 226, 234 (1876) (observing that "an invention so secured [under the patent statutes] is property in the holder of the patent, and that as such the right of the holder is as much entitled to protection as any other property," including the Fifth Amendment right against being "taken for public use without just compensation").

60. See Adam Mossoff, Patents as Constitutional Private Property, The Historical Protection of Patents under the Takings Clause, 87 B.U. L. REV. (forthcoming 2007).

61. See James v. Campbell, 104 U.S. at 358; see also Heaton v. Quintard, 11 F. Cas. 1008, 1009 (C.C.S.D.N.Y. 1869) (No. 6311) (commenting that the federal government retained an implied reservation to use a patent). Professor Mossoff notes that these comments were merely dicta and suggests that these doubts reflect oversights of prior decisions rather than intention to overrule such cases. See Mossoff, supra note 60.

62. See Steven J. Eagle, The Development of Property Rights in America and the Property Rights Movement, 1 GEO. J.L. \& PUB. POL'Y 77, 80-82 (2002). 
interest in his own person and, by extension, in the labor of his body, subject to there being "enough, and as good left in common for others." Upon this foundation, Locke asserted "life, liberty, and property" to be inalienable rights of a just society, which found resonance in the Declaration of Independence's proclamation of "Life, Liberty and the Pursuit of Happiness," as well as the Constitution's protection of private property. ${ }^{64}$ Following Locke's broad conception of property and its protection, ${ }^{65}$ the PRM advocates an absolutist approach to the protection of property rights and the most extreme limitations on government interference with and regulation of private property. Notwithstanding Locke's evident influence, the Founders had far more varied views of private property, as reflected, for example, in Benjamin Franklin's view that "Private Property... is a Creature of Society, and is subject to the Calls of that Society, whenever its Necessities shall require it, even to its last Farthing. . . ."66 Thus, the historical record of the Founders cannot fairly be characterized as supporting PRM's extreme reading of the Fifth Amendment. ${ }^{67}$

Various scholars have developed a utilitarian justification for universal and absolute property rights. The biologist Garrett Hardin offered the now classic parable of the "tragedy of the commons," which highlights the potential for overuse of resources that are not subject to exclusion. ${ }^{68}$ The economist Harold Demsetz posited that exclusive private property systems emerge as externalities become more prevalent and the

63. See John Locke, Two Treatises of Government 291 (Peter Laslett ed., Cambridge Univ. Press 1988) (1690).

64. Id; THE DECLARATION OF INDEPENDENCE para. 2 (U.S. 1776); U.S. CONST. amend. V ("nor shall private property be taken for public use without just compensation").

65. See LOCKE, supra note 63, at 209 ("[E]very man has a property in his own person . . ."); David Schultz, Political Theory and Legal History: Conflicting Depictions of Property in the American Political Founding, 37 AM. J. LEG AL HIST. 464, 472 (1993) (noting that Locke viewed "property" as "a general political term referring to all the personal and political rights of individuals").

66. See Benjamin Franklin, Queries and Remarks Respecting Alterations in the Constitution of Pennsylvania (1789), in 10 THE WRITINGS OF BENJAMIN FRANkLIN 54, 59 (Albert H. Smyth ed., 1907), cited in William Michael Treanor, The Original Understanding of the Takings Clause and the Political Process, 95 COLUM. L. REv. 782, 825 n.224 (1995).

67. See Robert H. Bork, The Tempting of America: The Political Seduction of THE LAW 230 (1990) ("My difficulty is not that Epstein's constitution would repeal much of the New Deal and the modern regulatory-welfare state but rather that these conclusions are not plausibly related to the original understanding of the takings clause."); John A. Humbach, "Taking" the Imperial Judiciary Seriously: Segmenting Property Interests and Judicial Revision of Legislative Judgments, 42 CATH. U. L. REV. 771, 776-77 (1993) (noting the ahistorical quality of interpreting the Takings Clause to reach beyond governmental expropriation to reach regulatory acts); Treanor, supra note 67 , at 825 (noting that the earliest state-based takings clauses were narrow, applying only to physical takings).

68. See Garrett Hardin, The Tragedy of the Commons, 162 SCI. 1243 (1968). 
costs of enforcing private property decline. ${ }^{69}$ Using a simple model of land cultivation, law and economics scholar Richard Posner asserted three criteria for an efficient allocation of land resources: (1) universality - that all land is owned, (2) exclusivity, and (3) transferability. ${ }^{70}$ Yet all of these theories apply in rather simple settings that overlook the economic and other values inherent in some public resources, such as roads and parks. As other scholars have pointed out, other governance regimes can succeed in various settings. ${ }^{71}$ Nonetheless, there is little question that the institution of private property has much to offer. $^{72}$

Even in relatively simple models, theories of intellectual property cannot be reduced to such straightforward criteria. While natural rights philosophers see both real and intellectual property as deriving from a common source - the labor of the creator ${ }^{73}$ - Locke's labor theory does not provide much traction beyond the question of initial ownership and some aspects of the scope of protection. ${ }^{74}$ Utilitarian theory has played

69. See Harold Demsetz, Toward a Theory of Property Rights, 57 AMER. ECON. REV. PAPERS \& PROC. 347 (1967).

70. See RichARD A. POSNER, ECONOMIC ANALYSIS OF LAW ch. 3 (6th ed. 2003); see also PROPERTY RightS: CONTRACT, CONFlict, AND LAW (Terry L. Anderson \& Fred S. McChesney eds., 2003).

71. See Robert C. Ellickson, Order Without law: How Neighbors Settle DisPuTES (1991); Michael Abramowicz, Perfecting Patent Prizes, 56 VAND. L. ReV. 115 (2003); Carol M. Rose, The Comedy of the Commons: Custom, Commerce, and Inherently Public Property, 53 U. CHI. L. REV. 711 (1986); Henry E. Smith, Exclusion Versus Governance: Two Strategies for Delineating Property Rights, 31 J. LEGAL STUD. 453 (2002); Brian D. Wright, The Economics of Invention Incentives: Patents, Prizes, and Research Contracts, 73 AM. ECON. REV. 691 (1983).

72. Robert C. Ellickson, Property in Land, 102 YALE L.J. 1315 (1993).

73. See Justin Hughes, The Philosophy of Intellectual Property, 77 GEO. L.J. 287 (1988); Alfred C. Yen, Restoring the Natural Law: Copyright as Labor and Possession, 51 OHIO ST. L.J. 517 (1990). Early American copyright statutes reflected the labor theory of property. See Jane C. Ginsburg, A Tale of Two Copyrights: Literary Property in Revolutionary France and America, 64 TUL. L. REV. 991, 1000 (1990) (explaining that "copyright lobbyists also invoked, on behalf of authors, the general Lockean principle that a property right arises out of one's labors"). Massachusetts directly invoked the labor theory in the preamble to its copyright statute:

As the principal encouragement such persons can have to make great and beneficial exertions of this nature, must exist in the legal security of the fruits of their study . . . and as such security is one of the natural rights of all men, there being no property more peculiarly a man's own than that which is procured by the labor of his mind.

Id. at 1001 (quoting Mass. Act of Mar. 17, 1783, reprinted in Copyright Off. Bull. No. 3, at 11 (1903)).

74. Locke's proviso-"enough, and as good be left in common for others"-cautions against the view that intellectual property rights should be absolute. See Wendy J. Gordon, $A n$ Inquiry into the Merits of Copyright: The Challenges of Consistency, Consent, and Encouragement Theory, 41 STAN. L. REv. 1343, 1446 n.445 (1989); Jeremy Waldron, From Authors to Copiers: Individual Rights and Social Values in Intellectual Property, 68 CHI.-KENT L. REV. 842 (1993). This theory would at most entitle creators to a property interest in the value they add by applying their labor to things removed from the commons, and not to the total value of the resulting product. See ROBERT NOZICK, ANARCHY, STATE AND UTOPIA 175-82 (1984); 
the principal role in determining the rights of intellectual property owners. The U.S. Constitution enshrines this instrumentalist perspective by authorizing Congress " $[\mathrm{t}]$ o promote the progress of science and useful arts, by securing for limited times to authors and inventors the exclusive right to their respective writings and discoveries." 75

In fostering this objective, neoclassical economists have taken a largely agnostic view as to the attributes of intellectual property. Rather than emulate real property rules and institutions, economists conceive of intellectual property as a malleable bundle of rights to be molded to promote progress of science and the arts. ${ }^{76}$ The "property" label carries little content other than the fact that intellectual property rights are generally owned and can be transferred. Economic conditions determine even the availability and duration of such rights.

The principal economic justification for intellectual property derives from a broader economic problem: the inability of a competitive market to support an efficient level of innovation in some areas of technological innovation-particularly those in which research and development (R\&D) is costly, innovation is easily perceived, and imitation is relatively inexpensive and can occur rapidly. A competitive economy will drive profits to zero, not accounting for sunk costs such as R\&D. Although imitation keeps prices low for consumers and avoids deadweight loss of monopolistic exploitation, it produces a sub-optimal level of investment in R\&D. ${ }^{77}$ Most firms would not invest in developing new technologies if rivals could enter the market and dissipate the profit before $R \& D$ costs adjusted for attendant risks could be recovered.

Unlike tangible goods, knowledge and creative works are public goods in the sense that their use is nonrivalrous. One agent's use does not limit another agent's use. Indeed, in its natural state, knowledge is also "nonexcludable." That is, even if someone claims to own the knowledge, it is difficult to exclude others from using it. Intellectual property law is an attempt to solve that problem by legal means; it grants exclusive use of the protected knowledge or creative work to the creator.

Such control, however, reduces social welfare in several ways. First, monopoly exploitation results in deadweight loss to consumers. Two other defects are that it may inhibit the use of scientific or technological

Lawrence C. Becker, Deserving to Own Intellectual Property, 68 CHI.-KENT L. REV. 609 (1993). Jeremy Waldron has convincingly argued that the "enough and as good" condition is a sufficient, but not a necessary condition for propertization. See Jeremy Waldron, Enough and as Good Left for Others, 29 PHIL. Q. 319 (1979).

75. U.S. CONST. art. I, $\$ 8$, cl. 8 (original capitalization removed).

76. See Peter S. MENell \& Suzanne SCOTChMER, INTEllectual Property Law, in HANDBOOK OF LAW AND ECONOMICS (A. Mitchell Polinsky \& Steven Shavell eds., forthcoming 2007).

77. See id. 
knowledge for further research, and, from an ex ante point of view, there is no guarantee that the research effort will be delegated efficiently to the most efficient firms, or even to the right number of firms.

Patent protection, for example, seeks to balance these competing effects by affording protection only to substantial (nonobvious) inventions, limiting the term of protection, and requiring that the inventor fully disclose the invention. ${ }^{78}$ In the most basic model of patent protection-where inventions do not serve as building blocks for later inventions and the only control variable is the duration of protectionWilliam Nordhaus showed how the optimal duration of patent protection balanced the incentives for innovation against the deadweight loss of monopoly exploitation. ${ }^{79}$

Cumulative innovation-where first generation inventions become inputs for second generation innovators-substantially complicates the design of patent protection. In order to reward first generation innovators sufficiently for inventions that may produce positive spillovers by enabling second generation inventions (improvements, new applications, and accessories), first generation innovators should be able to appropriate the value of second generation innovations. ${ }^{80}$ On the other hand, providing even a share of the second generation innovators' returns to the first generation innovator reduces the incentive for second generation innovators to pursue their research. ${ }^{81}$ This tension is abated to the extent that first generation innovators are best positioned to pursue second generation innovation or where collaboration (e.g., joint ventures) brings first and second generation innovation within the same profit center ${ }^{82}$ The cumulative nature of innovation unquestionably strengthens the case for allowing joint ventures, especially with respect to complementary products. ${ }^{83}$ In practice, however, one entity rarely is best positioned to pursue all second generation projects. Furthermore, second generation innovators are not known (and cannot be knowable) before the making of first generation research investments. Yet, once first generation research investments are made, they are sunk costs that become irrelevant for bargaining over the division of profits from multi-

78. See IPNTA, supra note 51, at 117-356.

79. See generally WILLIAM NORDHAUS, INVENTION, GROWTH AND WELFARE (1969).

80. See Suzanne Scotchmer, Standing on the Shoulders of Giants: Cumulative Research and the Patent Law, 5 J. ECON. PERSP. 29 (1991).

81. See id.

82. See Edmund W. Kitch, The Nature and Function of the Patent System, 20 J.L. \& ECON. 265 (1977).

83. See Michael Katz \& Janusz Ordover, $R \& D$ Competition and Competition, in BROOKINGS PAPERS ON ECONOMIC ACTIVITY, 137 (Martin N. Baily \& Clifford Winston eds., 1989); Suzanne Scotchmer, Patents as an Incentive System, in 2 ECONOMICS IN A CHANGING

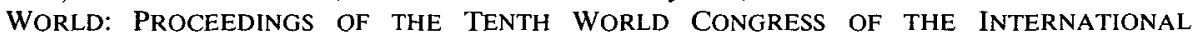
ECONOMIC ASSOClation, Moscow (Beth Allen ed., 1996). 
generation innovation. This problem can be addressed by expanding the duration and scope of first generation patents or by denying patent protection altogether to second generation innovation. ${ }^{84}$ These results, however, depend critically upon strong assumptions relating to licensing of innovation and the knowledge and rationality of innovators. As the institutional literature notes, there are many strategic impediments to licensing of innovation. ${ }^{85}$ In addition, much of the institutional literature casts doubt on the degree to which innovators possess good information for assessing the best diffusion path for their technologies and whether innovators behave rationally in licensing to actual and potential competitors. $^{86}$

The most important considerations in assessing the need for patent protection are the cost of research and development, the technological risk associated with such research, and the availability of effective nonpatent means of protection. Trade secret protection can afford some protection for process inventions, but relatively less for products. ${ }^{87}$ Furthermore, the availability of alternative means of protecting innovation - including direct public funding of innovation, other means of legal protection (copyright, trade secrecy, trademark), technical means of protection (e.g., metered access through the use of encryption), and market-based protections (lead-time/first mover advantage, ancillary means of appropriating a return to an invention (e.g., bundling access to a product or service with advertising), general reputational benefits) - can substitute for and in some cases obviate the need for patent protection. ${ }^{88}$ Patent protection may counteract the adverse effects of trade secrecy protection by promoting disclosure of knowledge. ${ }^{89}$ From an economic standpoint, therefore, the case for patent protection for particular types of inventions will vary.

The utilitarian linkage between property and intellectual property theory can be most directly traced to the law and economics literature. In a seminal 1977 paper, Professor Edmund Kitch analogized the patent system to mining law, suggesting that the first person to stake a claim to

84. See Jerry R. Green \& Suzanne Scotchmer, On the Division of Profit in Sequential Innovation, 26 RAND J. ECON. 20 (1995).

85. See, e.g., Robert P. Merges \& Richard R. Nelson, On the Complex Economics of Patent Scope, 90 Colum. L. REV. 839 (1990).

86. See Mark A. Lemley, The Economics of Improvement in Intellectual Property Law, 75 TEX. L. REV. 993 (1997).

87. Once products are distributed in the marketplace, competitors can take them apart to determine how they are constructed.

88. See generally SUZANNE SCOTCHMER, INNOVATION AND INCENTIVES (2004); Stephen G. Breyer, The Uneasy Case for Copyright, 84 HARV. L. REV. 281, 294-308 (1970); Peter S. Menell, Tailoring Legal Protection for Computer Software, 39 STAN. L. REV. 1329 (1987).

89. See David D. Friedman, William M. Landes \& Richard A. Posner, Some Economics of Trade Secret Law, 5 J. ECON. PERS. 61 (1991). 
an invention should be thought as obtaining a "prospect" or "development rights," authorizing the patent holder to "mine" the claim exclusively. ${ }^{90}$ Kitch defended this view of the patent system as promoting efficient (nonrivalrous) exploitation of innovation opportunities: technological advancement will proceed more desirably in such a regime because the first prospector will have "breathing room" to develop the claim without fear that rivals will preempt or steal the claim, and the inventor will be able to coordinate the development process. The opportunity to license the technology enables the inventor to contract with entities that may be better able to develop the claim. The prospect theory thus turns importantly upon a smoothly functioning technology licensing market and the capacity, foresight, and rationality of prospectors to coordinate the development and diffusion of the technology.

The optimality of private property as the model for intellectual property protection depends critically, however, on low transaction costs. But as others have shown, the assumption that low transaction costs are vital does not bear out in the history of many fields of innovation. Drawing on a wide range of empirical evidence and theoretical models of bounded rationality, Merges and Nelson see vibrant competition as a more positive force in spurring invention, innovation, and diffusion of technology than coordinated development by a single prospector. ${ }^{91}$ For this reason, narrower and weaker rights structures may be more efficacious in promoting innovation in particular fields.

Several other scholars have looked to the economics of real property in modeling intellectual property systems. William Landes and Richard Posner build their framework for understanding intellectual property on the economics of property rights in physical property. ${ }^{92}$ This framework compares the benefits (efficient use and cumulative innovation) and costs (transactional, rent seeking, and protection). While generally favoring strong, exclusive rights in intellectual property along the same lines as the rights commonly applied to tangible resources, Landes and Posner nonetheless recognize that "depropertizing' intellectual property may sometimes be the soundest policy economically" in some contexts. ${ }^{93}$ James Bessen and Michael Meurer find, for example, that the costs of business method and software patents (attributable to the inherent

\footnotetext{
90. See Kitch, supra note 82.

91. See Merges \& Nelson, supra note 85.

92. See William M. Landes \& Richard A. POSNer, THE ECONOMIC STRucture of INTELLECTUAL PROPERTY LAW 11-36 (2003).

93. Id. at 14 .
} 
ambiguity of rights boundaries) generally outweigh the relatively modest benefits of such patents. ${ }^{94}$

Other economic scholars have come to see "traditional" (i.e., tangible) property rules as a model for the design of intellectual property rules and institutions. Several scholars find that using property-type remedies (injunctions, or exclusive rights, as opposed to liability rules, which function as a form of court-imposed compulsory licenses) to enforce intellectual property rules can promote settlement and encourage the development of efficient licensing institutions. ${ }^{95}$ Yet in specific contexts, such as software and business methods, the asymmetry of stakes between nonmanufacturing patent holders on the one hand and start-up companies or established large-scale companies on the other may lead to undesirable opportunistic holdouts that distort $R \& D$ incentives, bargaining, and litigation. ${ }^{96}$

Professor Richard Epstein has pushed the functional relationship between real and intellectual property to the greatest extent. In a pamphlet prepared on behalf of the National Association of Manufacturers $^{97}$ as well as remarks at the Aspen Summit (organized by the Progress and Freedom Foundation, a libertarian think tank), ${ }^{98}$ Professor Epstein extols both the philosophical kinship of real and intangible assets and the utilitarian necessity of treating such resources similarly-particularly with regard to enforcement.

94. See James Bessen \& Michael Meurer, Do Patents Work? (unpublished manuscript, available at http://researchoninnovation.org/dopatentswork/ (last visited Apr. 24, 2007)).

95. See Thomas F. COTTER \& ROgER D. Blair, InTEllectual ProperTy: ECONOMIC AND LeGAL DIMENSIONS OF RIGHTS AND REMEdiES (2005); Robert P. Merges, Compulsory Licensing vs. the Three "Golden Oldies": Property Rights, Contracts, and Markets, CATO POLICY ANALYSIS No. 508 (Jan. 15, 2004), available at http://www.cato.org/ pub_display.php?pub_id=1366; Robert P. Merges, Contracting into Liability Rules: Intellectual Property Rights and Collective Rights Organizations, 84 CAL. L. REv. 1293, 1301 (1996) (concluding that in the context of complex transactions involving many players, a property rule will facilitate the creation of private exchange institutions, such as patent pools, that can evolve in response to changing circumstances and draw upon industry and institutional expertise); Robert P. Merges, Of Property Rules, Coase, and Intellectual Property, 94 COLUM. L. REV. 2655, 2664 (1994).

96. See Terrence P. McMahon, Stephen J. Akerley \& Jane H. Bu, Who Is a Troll? Not a Simple Answer, 7 SEDONA CONF. J. 159 (2006); Erica Werner, Lawmakers Want to Crack Down on Patent Trolls, ASSOCIATED PRESS, June 8, 2005, available at http:/www.signonsandiego.com/ news/computing/20050608-1429-congress-patents.html; Larmar Smith, Congressman, Remarks Before the Conference on Patent Reform (June 9, 2005), http://www.lamarsmith.house.gov/ News.asp?FormMode=Detail\&ID=650; cf. Meurer, Controlling Opportunistic and Anti-Competitive Intellectual Property Litigation, supra note 14.

97. See Richard A. EPSTEIN, InTEllectual Property for the TeChNological AGE (2006).

98. See Epstein, Structural Unity, supra note 22. 


\section{EBAY V. MERCEXCHANGE: AN INAUSPICIOUS FIRST DATE}

The Supreme Court's decision to hear eBay's challenge of the Federal Circuit's permanent injunction standard served as a flirtatious enticement for the PRM's first date with intellectual property owners. Professor Epstein saw this as an opportunity to push the property rights agenda into the intangible domain by asserting that exclusive patent rights meant that the patent owner should be free to decide who may use a claimed invention. The eBay case posed the question of whether and under what circumstances courts could force patent owners to make their inventions available through the payment of infringement damages (as opposed to a permanent injunction).

To place the PRM's embrace of intellectual property in context, Section A describes the confluence of factors that led to the eBay litigation. Section B describes the MercExchange patent and the lower court litigation. Section $C$ examines the Supreme Court litigation, focusing upon Professor Epstein's private property rights advocacy. The final section reviews the outcome of the case.

\section{A. The Rise of Business Method Patents}

The eBay litigation grew out of several important technological, institutional, legal, and administrative developments of the last two decades of the twentieth century. The digital revolution taking place during this time frame generated a flurry of technological advances, most notably the Internet. The Internet proved a fertile environment for new business methods, including the online auction. eBay emerged as one of the great Internet success stories. Founded in late 1995, eBay proved the power of the Internet to reach large consumer audiences at relatively low cost. ${ }^{99}$ Within just a few years, eBay had attracted a large and devoted audience for the most diverse marketplace bazaar in human history.

None of this story would have come to the attention of the U.S. Supreme Court without a dramatic expansion of patent protection during this time period. This expansion resulted largely from institutional changes rather than a deliberate legislative shift in patent policy. Prior to the early 1980 s, patent enforcement decisions were appealed to the courts of appeals in the same region as the trial court. This decentralization of appellate decision making generated distinct patterns of patent case law. Some circuits developed reputations for being "patent friendly" while others were skeptical of patent protection, resulting in quite a bit of

99. See Adam Cohen, The Perfect Store: Inside eBay (2002); Daniel Nissanoff, FutureShop: How the NeW Auction Culture Will ReVolutionize the WAy We BuY, SEll and Get THE THings We Really WaNT (2006). 
forum shopping. ${ }^{100}$ Congress sought to address this problem in 1982 by establishing the U.S. Court of Appeals for the Federal Circuit to hear all patent appeals. ${ }^{101}$

While effectively eliminating the forum shopping driven by differences in appellate standards, the unification of appellate decision making in a single body had the effect of creating a strong pro-patent bias in the interpretation of patent law. ${ }^{102}$ For much of the 1980s and 1990s, the Federal Circuit significantly expanded and strengthened patent protection. Among the more notable changes were to lower the obviousness requirement ${ }^{103}$ and largely eliminate subject matter constraints on patentability. The Federal Circuit's 1998 State Street Bank case "laid to rest" the traditional rule barring patents on business methods. ${ }^{104}$

These changes spurred tremendous growth in patent filings at the same time that the U.S. Patent and Trademark Office (PTO) was undergoing difficult funding and staffing challenges. ${ }^{105}$ The result has been a flood of patents in the software and business method areas of questionable necessity (from the standpoint of encouraging innovation) and validity (e.g., Amazon.com's one-click patent ${ }^{106}$ and NTP's patent on wireless e-mail $\left.{ }^{107}\right)$.

100. See Rochelle Cooper Dreyfuss, The Federal Circuit: A Case Study in Specialized Courts, 64 N.Y.U. L. REV. 1, 7 (1989).

101. See Federal Court Improvements Act of 1982, Pub. L. No. 97-164, 96 Stat. 25 (1982).

102. See LANDES \& POSNER, supra note 92, at 334-53; ADAM B. JAFFE \& JOSH LERNER, INNOVATION AND ITS DISCONTENTS: HOW OUR BROKEN PATENT SYSTEM IS ENDANGERING INNOVATION AND PROGRESS, AND WHAT TO DO ABOUT IT 101-03 (2004) (noting that members of Congress as well as commentators worried that the creation of a specialized patent court could create tunnel vision).

103. See JAFFE \& LERNER, supra note 102, at 119-25; John H. Barton, Nonobviousness, 43 IDEA 475, 478 (2003); Glynn S. Lunney, Jr., E-Obviousness, 7 MiCh. TelECOMM. \& TECH. L. REV 363 (2001).

104. See State Street Bank \& Trust Co. v. Signature Fin. Group, Inc., 149 F.3d 1368 (Fed. Cir. 1998), cert. denied, 525 U.S. 1093 (1999).

105. See JAFFE \& LERNER, supra note 102, at 127-50.

106. See Method and System for Placing a Purchase Order Via a Communications Network, U.S. Patent No. 5,960,411 (filed Sept. 28, 1999); Amazon.com, Inc. v. Barnesandnoble.com, Inc., 239 F.3d 1343 (Fed. Cir. 2001) (finding substantial questions as to the validity of the patent); James Gleick, Patently Absurd, N.Y. TiMes MAG., Mar. 12, 2000, at 44.

107. See Electronic Mail System with RF Communications to Mobile Processors and Method of Operation Thereof, U.S. Patent No. 5,436,960 (filed July 25, 1995); Tim Wu, Weapons of Business Destruction: How a Tiny Little "Patent Troll" Got BlackBerry in a Headlock, SLATE, Feb. 6, 2006, http:// www.slate.com/ id/2135559/ (describing NTP as a company that has "no . . . assets, no products, and no employees"). Upon reexamination, the PTO determined several of NTP's patents to be invalid. See Stephanie Stoughton, BlackBerry screens won't go dark just yet, USATODAY.com (Feb. 24, 2006) available at http://www.usatoday.com/money/industries/technology/2006-02-24-blackberry-battle_x.htm;

Declan McCullagh, Judge to RIM: We're not delaying this any longer, CNET NEWS.COM (Nov. 30, 2005), available at http:// news.com.com/2100-1041_3- 5976776.html. 


\section{B. The MercExchange Patents and the Enforcement Proceedings}

Just as the Internet was beginning to attract attention in the mid1990s, Thomas G. Woolston, an electrical engineer with a law degree, came up with the idea of creating an online auction system. ${ }^{108}$ Without significant investment, he wrote code for an online auction and filed for patents to protect his method and system in April 1995. He ultimately acquired three patents based on this work: (1) U.S. Patent No. 5,845,265 (issued Dec. 1, 1998), entitled "Consignment Nodes"; No. 6,085,176 (issued July 4, 2000), entitled "Method and Apparatus for Using Search Agents to Search Plurality of Markets for Items"; ${ }^{110}$ and (3)

108. See Ellen McCarthy, Waiting out a Patent Fight with EBay, WASH. POST, Jan. 6, 2005, at E01; The eBay Patent Wars and Timeline, http://www.auctionbytes.com/cab/pages/patent.

109. The abstract states:

A method and apparatus for creating a computerized market for used and collectible goods by use of a plurality of low cost posting terminals and a market maker computer in a legal framework that establishes a bailee relationship and consignment contract with a purchaser of a good at the market maker computer that allows the purchaser to change the price of the good once the purchaser has purchased the good thereby to allow the purchaser to speculate on the price of collectibles in an electronic market for used goods while assuring the safe and trusted physical possession of a good with a vetted bailee.

The first claim states:

A system for presenting a data record of a good for sale to a market for goods, said market for goods having an interface to a wide area communication network for presenting and offering goods for sale to a purchaser, a payment clearing means for processing a purchase request from said purchaser, a database means for storing and tracking said data record of said good for sale, a communications means for communicating with said system to accept said data record of said good and a payment means for transferring funds to a user of said system, said system comprising:

a digital image means for creating a digital image of a good for sale;

a user interface for receiving textual information from a user;

a bar code scanner;

a bar code printer;

a storage device;

a communications means for communicating with the market; and

a computer locally connected to said digital image means, said user interface, said bar code scanner, said bar code printer, said storage device and said communications means, said computer adapted to receive said digital image of said good for sale from said digital image means, generate a data record of said good for sale, incorporate said digital image of said good for sale into said data record, receive a textual description of said good for sale from said user interface, store said data record on said storage device, transfer said data record to the market for goods via said communications means and receive a tracking number for said good for sale from the market for goods via said communications means, store said tracking number from the market for goods in said data record on said storage device and printing a bar code from said tracking number on said bar code printer.

110. The abstract for U.S. Patent No. $6,085,176$ is the same as for U.S. Patent No. 5,845,265. See supra note 109 . The first claim in U.S. Patent No. 6,085,176 states: 
U.S. Patent No. 6,202,051 (issued Mar. 13, 2001), entitled "Facilitating Internet Commerce Through Internetworked Auctions."111

Woolston's first business venture based on these systems foundered. ${ }^{112}$ After his first patent issued in December 1998, he was able to raise $\$ 10$ million for MercExchange, an online travel venture. In addition to pursuing this business opportunity, MercExchange set out to enforce its patents. Its first lawsuit targeted GoTo.com, an online advertising company. In 2000, MercExchange's General Counsel met with an eBay representative and began discussion over MercExchange's patents. By the middle of that year, MercExchange's online travel business had collapsed and it focused its efforts on selling or licensing its patents to eBay. In 2001, MercExchange reached a $\$ 4$ million settlement agreement with GoTo.com. In September, it filed suit against eBay, Half.com (a company purchased by eBay), and ReturnBuy (an eBay affiliate) asserting the ' 265 , ' 176 , and ' 051 patents.

The case came before District Judge Jerome Friedman in the Eastern District of Virginia. It attracted substantial attention and was characterized as pitting David (MercExchange) against Goliath (eBay). During the pre-trial process, Judge Friedman granted eBay's summary

A method of searching a plurality of electronic markets to locate an item, the method comprising:

receiving a search request for an item from an internet participant at a first computer; formatting said search request at said first computer into a predetermined format;

transmitting said search request, using a software search agent, from said first computer to a plurality of other computers in said predetermined format, at least one of the plurality of other computers performing a search for the item in response to receiving said search request;

and receiving at the first computer search results from at least one of the plurality of other computers in response to the transmitted search request.

111. The abstract states:

Auctioning an uniquely identified item (e.g., used goods or collectibles) with a computerized electronic database of data records on the Internet includes creating a data record containing a description of an item, generating an identification code to uniquely identify the item, and scheduling an auction for the item at the computerized database of records. The item is presented for auction to an audience of participants through a worldwide web mapping module executing in conjunction with the computerized database. The data record connotes an ownership interest in the item to a seller participant on the computerized electronic database of data records.

The worldwide web mapping module translates information from the data record on the computerized database of records to a hypertext markup language (HTML) format for presentation through the Internet. Bids are received on the item from participants on the Internet through an auction process that executes in conjunction with the computerized database of data records. Auctioning of the item is terminated when the auction process reaches predetermined criteria. The auction participant is notified of the high bid in the auction process. The unique identification code is provided to the auction participant with the high bid to uniquely identify the item.

112. See McCarthy, supra note 108 . 
judgment motion asserting invalidity of the ' 051 patent for inadequate written description and construed the ' 265 and ' 176 patents in such a way that they did not implicate eBay's core auction technology. ${ }^{113}$ Judge Friedman allowed two narrower infringement allegations-relating to search technology and allowing consumers to buy some products on auction sites at a fixed price-to proceed to trial. After a five-week trial, the jury ruled for MercExchange and awarded damages of $\$ 35$ million. In post-trial rulings, Judge Friedman reduced the damage award to $\$ 29.5$ million. ${ }^{114}$

The issue that would ultimately attract the Supreme Court's attention was Judge Friedman's decision to deny MercExchange a permanent injunction. While recognizing the "property" nature of patents and the general rule favoring issuance of permanent injunctions when infringement has been found absent extraordinary circumstances, Judge Friedman assiduously applied the equitable principles guiding the exercise of injunctive relief: "(i) whether the plaintiff would face irreparable injury if the injunction did not issue, (ii) whether the plaintiff has an adequate remedy at law, (iii) whether granting the injunction is in the public interest, and (iv) whether the balance of the hardships tips in the plaintiff's favor."115

Notwithstanding the presumption of irreparable harm applied after the establishment of patent validity and infringement, Judge Friedman determined that eBay had rebutted the presumption on the basis of two showings: (1) that MercExchange "did not practice its inventions and exists merely to license its patented technology to others";116 and (2) that MercExchange had not sought a preliminary injunction. ${ }^{117}$ As to the adequacy of the remedy at law, Judge Friedman departed from the weight of Federal Circuit precedent suggesting that monetary damages are usually inadequate to compensate for patent infringement on the ground that this was "an atypical case." 118 He elaborated in his discussion of the public interest, in which he cited "growing concern over the

113. See MercExchange, L.L.C. v. eBay, Inc., 275 F. Supp. 2d 695, 711-15 (E.D. Va. 2003), aff'd in part and rev'd in part, 401 F.3d 1323 (Fed. Cir. 2005), vacated, 126 S. Ct. 1837 (2006).

114. See id. at 722 .

115. See id. at 711 (quoting Odetics, Inc. v. Storage Tech. Corp., 14 F. Supp. 2d 785, 794 (E.D. Va.1998) (citing Weinberger v. Romero-Barcelo, 456 U.S. 305, 312 (1982)), aff'd, 185 F.3d 1259 (Fed. Cir. 1999)).

116. Id. at 712 . The court cited to public statements by MercExchange's representatives that it was seeking "reasonable royalties" and was not interested in putting eBay out of business, see Troy Wolverton, Patent Suit Could Sting eBay (Sept. 5, 2002), http://news.com.com/2100-1017956638.html (quoting Scott Robinson, Attorney for MercExchange), and that it was interested in selling its intellectual property rights, see Ina Steiner, eBay-Contested MercExchange Patents are on the Block (May 30, 2003), http://www.auctionbytes.com/cab/abn/y03/m05/i30/s01 (quoting Thomas Woolston).

117. See MercExchange, 275 F. Supp. $2 \mathrm{~d}$ at 712.

118. See id. at 713 . 
issuance of business-method patents," citing the PTO's decision to implement a second round of review for this class of patents and 2001 legislation establishing a prior user right for business method patents. Judge Friedman determined that the concern about business method patents offset the public interest in maintaining the integrity of the patent system by favoring the patentee's interest in injunctive relief. In assessing the balance of hardships, Judge Friedman noted both the potential for ongoing litigation if he ordered a permanent injunction (due to the difficulty of determining the adequacy of eBay's "work arounds" of MercExchange's patent claims) and the potential problems of monitoring and quantifying damages for infringing activity in the absence of an injunction. On the basis of all of these factors, Judge Friedman concluded that the balance of hardships tipped "slightly" in eBay's favor. ${ }^{119}$

On appeal, the Federal Circuit upheld the findings of validity and infringement regarding the ' 265 patent, ${ }^{120}$ which brought the denial of the permanent injunction to the fore. In setting a high bar for the denial of permanent injunctions after a finding of infringement, the appellate court invoked the property nature of patents: "Because the 'right to exclude recognized in a patent is but the essence of the concept of property,' the general rule is that a permanent injunction will issue once infringement and validity have been adjudged." 21 The court limited departures from the general rule to circumstances in which "'a patentee's failure to practice the patented invention frustrates an important public need for the invention,' such as the need to use an invention to protect public health." 122 The Federal Circuit rejected the lower court's "general concern regarding business-method patents," findings regarding continuing litigation, MercExchange's public statements regarding its willingness to license its patents, and its failure to seek a preliminary injunction as sufficient to justify departure from the general rule. ${ }^{123}$ The Federal Circuit specifically emphasized that injunctions should be "equally available to both" those who practice their patented inventions and those who don't. ${ }^{124}$

119. Id. at 714

120. See MercExchange, L.L.C. v. eBay, Inc., 401 F.3d 1323 (Fed. Cir. 2005), vacated, 126 S. Ct. 1837 (2006). The court invalidated the '176 patent for lack of novelty and overturned the grant of summary judgment with regard to the ' 051 patent.

121. See id. at 1338 (quoting Richardson v. Suzuki Motor Co., 868 F.2d 1226, 1246-47 (Fed. Cir. 1989)).

122. See id. (quoting Rite-Hite Corp. v. Kelley, Inc., 56 F.3d 1538, 1547 (Fed. Cir. 1995)).

123. See id. at 1339 .

124. See id. 


\section{The Supreme Court Battle and the PRM's Embrace of Intellectual Property}

Even before the eBay case arose, reports by both the Federal Trade Commission ${ }^{125}$ and the National Academy of Sciences ${ }^{126}$ called attention to a growing patent crisis, with particular emphasis on the problems surrounding business method patents. ${ }^{127}$ The rise in litigation brought by nonpracticing entities, labeled "trolls" by some in the industry, has increasingly troubled information technology companies. ${ }^{128}$ These companies pushed draft patent reform legislation seeking to relax the standard for injunctive relief. ${ }^{129}$

Thus, eBay had little difficulty generating press coverage for its efforts or mobilizing a coalition in support of a petition for a grant of certiorari. The Computer and Communications Industry Association, the Electronic Frontier Foundation, and a large group of law professors supported eBay's petition for certiorari, while Qualcomm (a wireless technology patent holder) in conjunction with another information technology patentee and a biotechnology patentee, weighed in on behalf of MercExchange. ${ }^{130}$ The Supreme Court granted certiorari in late November 2005. ${ }^{131}$

The Supreme Court received more than a dozen briefs on each side of the dispute. eBay received strong and broad support from the information technology sector as well as the securities industry and a large coalition of law professors. MercExchange had the support of the pharmaceutical industry, the biotechnology industry, several large broadbased technology companies (General Electric, 3M, DuPont, and Johnson \& Johnson), the federal government, national patent law organizations (the American Bar Association and the American Intellectual Property Law Association), university licensing offices,

125. See FTC REPORT, supra note 14.

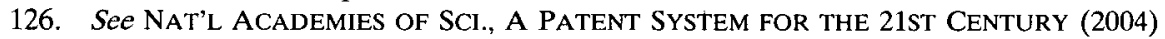
[hereinafter NAS REPORT].

127. See FTC REPORT, supra note 14, ch. 3, at 55-56; NAS REPORT, supra note 126, at 90; see also Dreyfuss, supra note 14; Meurer, Business Methods and Patent Floods, supra note 14; Meurer, Controlling Opportunistic and Anti-Competitive Intellectual Property Litigation, supra note 14 .

128. See, e.g., McMahon, Akerley \& Bu, supra note 96.

129. See Patent Reform Act of 2005, H.R. 2795, 109th Cong. (2005); Peter Geier, Bill in Congress to Overhaul Patent Law Seeks to Quell Suits-Support Seen to Make U.S. System More Consistent with Others, NAT'L L.J., Aug. 19, 2005, available at http://www.law.com/ jsp/article.jsp?id=1124109330603 (emphasizing that the draft legislation pits pharmaceutical and biotechnology companies against information and software technology firms on the issue of the standard and scope of injunctions).

130. See Patently-O: The Patent Law Blog, Ebay v. MercExchange: The Law of Patent Injunctions (Mar. 14, 2006), http://patentlaw.typepad.com/patent/2006/03/ebay_v_mercexch.html (collecting briefs).

131. See eBay Inc. v. MercExchange, L.L.C., 126 S. Ct. 733 (2005). 
patent holding (licensing) companies, and a smaller group of law professors. ${ }^{132}$ In many respects, the amici arguments on each side largely tracked the parties' arguments.

The brief co-authored by Professors Epstein, Kieff, and Wagner filed on behalf of "Various Law and Economics Professors" in 'support of MercExchange placed particular emphasis on the analogy between real and intellectual property in defending the Federal Circuit's general rule favoring the granting of permanent injunctions in patent cases. The Epstein Brief emphasized that courts generally grant injunctive relief for violations of real property rights ${ }^{133}$ and then urged the Court to look to principles of real property law in articulating the patent law injunctive standard:

The conclusion on this point is not unique to the patent law but applies to areas of land law including nuisance and encroachment. In these cases, the use of injunctions is in general more common than is sometimes supposed in academic debates. See generally, Henry E. Smith, Property and Property Rules, 79 N.Y.U.L. Rev. 1719 (2004). The caselaw offers this example on encroachment: one landowner builds a large structure whose foundation is a short distance over the boundary line. One possible remedy is to allow the forced purchase whereby the encroaching owner pays his neighbor the fair market value of the small strip of land taken. That approach is generally rejected and the landowner is usually allowed to require the removal of the structure, even at high positive cost. See Geragosian v. Union Realty Co., 193 N.E. 726 (Mass. 1935). In that case the Court proceeded just as did the Federal Circuit below, by identifying the reasons that either fail or suffice in justifying the injunction:

The facts that the aggrieved owner suffers little or no damage from the trespass, that the wrongdoer acted in good faith and would be put to disproportionate expense by removal of the trespassing structures, and that neighborly conduct as well as business judgment would require acceptance of compensation in money for the land appropriated are ordinarily no reasons for denying an injunction. Rights in real property cannot ordinarily be taken from the owner at a valuation, except under the power of eminent domain. Only when there is some estoppel or laches on the part of the plaintiff or a refusal on his part to consent to acts necessary to the removal or abatement

132. The briefs are collected and profiled at Patently-O. See Patently-O, supra note 130.

133. The Epstein Brief takes particular aim at the suggestion in the brief filed by fifty-two professors in support of eBay that "traditional principles of equity" invite courts to "consider such factors as adequate remedy at law, the balance of hardships to the parties, and the public interest in deciding whether to grant the injunction." See Brief of 52 Intellectual Property Professors as Amici Curiae in Support of Petitioner at 4. The Epstein Brief shows that the cases relied upon for this proposition "require the suspension of exclusive rights in land in order to deal with some disaster or calamity, or with the exercise of sovereign power." Epstein Brief, supra note 17 , at 11 . 
which he demands will an injunction ordinarily be refused. Id. at 728 (citations omitted).

Oftentimes the doctrinal explanation for this result is that the right in land is a right to exclude, period. But the functional explanation is that being tough in a small number of cases may cause needless disruption in them-but at the same time it produces a long-term systematic gain because it reduces the number of infringements that take place. There is, at the edge of this doctrine, some small degree of discretion, which is not exercised in cases of deliberate trespass but may be exercised in cases of innocent trespass (i.e. those discovered only after completion). ${ }^{134}$

The Epstein Brief's blithe reference to an old encroachment case is questionable in at least two respects. This selective reference to the Geragosian case overlooks statutory and case law shifting away from the very bright-line, rigid rules to what have been referred to as "good faith" improver rules that afford jurists equitable discretion in encroachment cases. ${ }^{135}$ More significantly, extrapolating from real property law to intellectual property law overlooks important distinctions between the underlying resources at issue. I examine those differences below.

\section{Post-Mortem: A Disappointing First Date}

The Supreme Court declined the suggestion to treat this case by reference to real property and unanimously reversed the Federal Circuit's decision. ${ }^{136}$ In a concise opinion written by Justice Thomas, the Court held that the traditional four-factor balancing test employed by courts of equity in evaluating whether to award permanent injunctions should apply with equal force in patent cases. In so doing, the Court rejected the Federal Circuit's presumption that permanent injunctions should issue after findings of infringement in the absence of "extraordinary circumstances" "to protect the public interest." Justice Thomas's opinion also questioned the district court's basis for denying the permanent injunction. The Court remanded the case for full consideration of the traditional multi-factor test.

The concurring opinions shed more light on how Professor Epstein's argument in favor of the categorical approach fared among the members of the Court. Chief Justice Roberts, in an opinion joined by Justices Scalia and Ginsburg, shows some sympathy for the "property rights" view. The opinion notes that the "long tradition" of granting permanent injunctive relief in the vast majority of patent cases in which infringement had been found reflected the "difficulty of protecting a right to exclude

134. Epstein Brief, supra note 17, at 16-17.

135. See, e.g., Raab v. Casper, 124 Cal. Rptr. 590 (Ct. App. 1975).

136. See eBay Inc. v. MercExchange, L.L.C., 126 S. Ct. 1837 (2006). 
through monetary damages." ${ }^{137}$ Chief Justice Roberts closed by calling for caution in departing from tradition, invoking Justice Holmes' observation that "'a page of history is worth of volume of logic." 138 Justice Kennedy, joined by Justices Stevens, Souter, and Breyer, emphasized the need to adapt the standards for injunctive relief to the evident changes taking place in the patent field. ${ }^{139}$ The Kennedy opinion suggests that courts should be more cautious in the granting of permanent injunctions under various circumstances arguably present in the eBay case: the use of patents by nonmanufacturing entities to charge "exorbitant fees" 140 and the vague and suspect validity of business method patents. ${ }^{141}$

Despite the differences between the two concurrences, the case largely repudiates the "intellectual property equals property" proposition. None of the Justices invoked real property law. Chief Justice Roberts's "a page of history" refers to patent history, not real property history. None of the Justices emphasized the sanctity of property. Even Chief Justice Roberts focused on the problem of the adequacy of compensation, saying nothing of natural rights.

Professor Epstein did not react well to the Court's decision:

What is so hard to comprehend about this dismal performance is the utter lack of attention to the basic structure of an industry in which literally trillions of dollars depend on the sound operation of a patent system. The troll problem occupies a little corner of this vast universe, and yet the Court seems to be prepared to impose massive indecision and uncertainty on the entire system without ever stopping to think how it actually works. ${ }^{142}$

Lower courts' readings of the eBay decision no doubt have deepened Professor Epstein's disappointment. Whereas the denial of permanent injunctive relief following an infringement finding was rare prior to the $e$ Bay case, there has been a significant increase in the percentage of cases denying permanent injunctions in just the nine months since the eBay case came down. Of sixteen decisions between May 15, 2006 and February 10, 2007 involving nonpracticing patentees, courts have denied permanent injunctions in six. ${ }^{143}$

137. Id. at 1841 (Roberts, C.J., concurring).

138. Id. at 1842 (quoting New York Trust Co. v. Eisner, 256 U.S. 345, 349 (1921)).

139. See id. at 1843 (Kennedy, J., concurring) (citing FTC REPORT, supra note 14, at 38-39).

140. This seems to be a veiled reference to what has come to be characterized as the problem of "patent trolls." See McMahon, Akerley \& Bu, supra note 96.

141. See eBay, 126 S. Ct. at 1842 (Kennedy, J., concurring).

142. See Richard A. Epstein, Court Soft on Property Rights, FIN. TIMES, May 16, 2006. Epstein's reaction may well reflect the fact that his principal exposure to patent law has come in the pharmaceutical area. As reflected in the eBay case, the "troll problem" is rampant in the software field. See McMahon, Akerley \& Bu, supra note 96.

143. See IMX, Inc. v. LendingTree, L.L.C., 469 F. Supp. 2d 203 (D. Del. 2007) (due in part to patentee's failure to supplement the record after $e B a y$, motion for permanent injunction "denied without prejudice to renew subsequent to any appeal by the parties relating to issue of 
The effects of this balancing approach on economic performance and innovation are unlikely to be disastrous. Reducing the economic power of patent licensing companies in the software/business method space could well promote innovation and competition. But the eBay decision undoubtedly reduces the "exclusivity" of intellectual property. And if strengthening such rights is the goal of intellectual property (IP) law, this resalt may well be a harbinger of disappointments to come in fitting intellectual property into the property mold.

\section{SOURCES OF TENSION IN THE PRM-IP RELATIONSHIP}

This eBay encounter was no blind date. Professor Epstein began courting intellectual property owners about a decade ago and had shown his interest half a dozen years ago in questioning a governmental proposal to use its power of eminent domain to ensure availability of Cipro in the event of an anthrax emergency. ${ }^{144}$ But the depth of his affection did not become fully apparent until the eBay case. Given Professor Epstein's persistence in pressing a libertarian property-rights agenda, it is worth considering whether this foray into intellectual property advocacy is likely to develop into a deeper, longer-term relationship.

For any relationship to succeed, it must further the joy and aspirations of both parties. The PRM undoubtedly seeks to press its core agenda of strengthening the rights of traditional property owners. For a relationship with intellectual property owners to work for the PRM, it has to enhance the exclusivity and enforceability of property rights and limit

infringement, validity, or wilfulness"); Sundance, Inc. v. DeMonte Fabricating Ltd., No. 02-73543, 2007 WL 37742 (E.D. Mich. Jan. 4, 2007); Voda v. Cordis Corp., No. CIV-03-1512-L, 2006 WL 2570614 (W.D. Okla. Sept. 5, 2006); Finisar Corp. v. DirecTV Group, No. 1:05-CV-264, 2006 WL 2709206 (E.D. Tex. Sept. 1, 2006); Paice LLC v. Toyota Motor Corp., No. 2:04-CV-211DF, 2006 WL 2385139 (E.D. Tex. Aug. 16, 2006); z4 Techs. v. Microsoft Corp., 434 F. Supp. 2d 437 (E.D. Tex. 2006); see also Monsanto Co. v. Scruggs, 459 F.3d 1328 (Fed. Cir. 2006) (trial court's permanent injunction order vacated, and the case remanded, for complete analysis under the eBay test). Injunctions were ordered in the following cases: MPT, Inc. v. Marathon Labels, Inc., No. 1:04-cv-2357, 2007 WL 184747 (N.D. Ohio Jan. 19, 2007); Transocean Offshore Deepwater Drilling, Inc. v. GlobalSantaFe Corp., No. H-03-2910, 2006 WL 3813778 (S.D. Tex. Dec. 27, 2006); Black \& Decker Inc. v. Robert Bosch Tool Corp., No. 04-C-7955, 2006 WL 3446144 (N.D. Ill. Nov. 29, 2006); Rosco v. Mirror Lite Co., No. CV-96-5658, 2006 WL 2844400 (E.D.N.Y. Sept. 29, 2006); Smith \& Nephew, Inc. v. Synthes (U.S.A.), 466 F.Supp.2d 978 (W.D. Tenn. 2006); 3M Innovative Props. Co. v. Avery Dennison Corp., No. 01-1781, 2006 WL 2735499 (D. Minn. Sept. 25, 2006); Floe Int'l, Inc. v. Newmans' Mfg. Inc., No. 04-5120, 2006 WL 2472112, at *9 (D. Minn. Aug. 23, 2006); Tivo Inc. v. Echostar Commc'ns Corp., 446 F. Supp. 2d 664 (E.D. Tex. 2006); Telequip Corp. v. Change Exchange, No. 5:01-CV-1748, 2006 WL 2385425 (N.D.N.Y. Aug. 15, 2006); Wald v. Mudhopper Oilfield Servs., No. CIV-04-1693-C, 2006 WL 2128851 (W.D. Okla. July 27, 2006). See generally The Fire of Genius, http://www.thefireofgenius.com/injunctions (last visited Apr. 22, 2007).

144. See Epstein, Respect Bayer's Patent: Cheap Cipro Now Could Cost Us Dearly in the Long Run, supra note 22. 
government interference with traditional property rights generally. On the other side, intellectual property owners have to believe that their profitability will increase to the extent that intellectual property rights are viewed in much the same way as real property interests.

This section casts doubt on the viability of such a relationship. Using the construct of matchmaking theory, ${ }^{145}$ it explores four fundamental differences between the PRM and intellectual property owners that will likely stand in the way of a mutually satisfying relationship. Less facetiously, this analysis reveals the limitations of the equation of real and intellectual property.

\section{A. Philosophical and Religious Differences}

Although successful "mixed" marriages are not uncommon in today's heterogenous society, religious differences can generate strain on any relationship. Just as in conventional relationships - Who will conduct the marriage ceremony? What holidays will be observed? How will the children be raised? - philosophical differences between interest groups can generate significant discord. This seems likely in the union of the libertarian/natural rights-driven PRM and the utilitarian intellectual property owners.

These two groups differ significantly on a fundamental issue - the nature of private property rights. For PRM advocates, this is the raison d'être. They cherish, almost worship, private property rights and their protection from governmental interference. ${ }^{146}$ By contrast, most intellectual property owners see intellectual property rights as a means to an end. Their principal goal is typically to profit from their investments in technology or expressive creativity. They tend to be far more agnostic about government interventions. In fact, several important fields of endeavor-such as biomedical research and defense-related technologies-depend principally upon government support and encouragement. ${ }^{147}$ Universities play a significant and growing role in the

145. See JOSEPH STEIN, JERRY BOCK, \& SHELDON HARNICK, FIDDLER ON THE ROOF: BASEd ON SHOlOM AleICHEM's STORIES (2004) (Yenta's role); PHIL MCGRAW (a.k.a. "Dr. Phil"), LOVE SMART: FIND THE ONE YOU WANT - FIX THE ONE YOU GOT (2005).

146. See Kendall \& Lord, supra note 1 . In a poignant irony, Pfizer, a leading drug company for whom Professor Richard Epstein has worked on intellectual property advocacy, see Richard A. Epstein, What's Good for Pharma is Good for America, Boston GloBE, Dec. 3, 2006 (noting in the biographical footnote that Professor Epstein has "consulted for Pfizer"), was the company for whom Susette Kelo's land was condemned. See Kelo v. City of New London, 545 U.S. 469,473 (2005).

147. See Ted Agres, US Biomedical Research Funding Doubles, with Help from Industry, THE SCIENTIST, Oct. 10, 2005, at 47, available at http://www.the-scientist.com/article/ display/15780/ (reporting that the National Institutes of Health provided 28 percent of total biomedical research funding). 
intellectual property system and their interests are even more intertwined with the government.

A relatively small pocket of creators - typically artists-come closer to the PRM's zeal for property rights through advocacy for moral rights. ${ }^{148}$ Yet the artists' moral rights framework diverges fundamentally from at least one the PRM's core principles. Moral rights advocates see an important role for rules of inalienability, ${ }^{149}$ going so far as to bar destruction of works of "recognized stature"150 even by the owner. This view of copyright clearly diverges from the concept of a fee simple absolute. Thus, the PRM and intellectual property constituencies bring very different moral compasses to the relationship.

\section{B. Functional Differences}

As we know from rates of successful intermarriage, true love can overcome religious differences in some relationships. The depth of religious conviction among property rights enthusiasts would certainly test the PRM-IP union. The differences between real and intellectual property, however, go well beyond religion. The PRM's unidimensional approach to property rights diverges from the multi-faceted needs (and desires) of intellectual property owners and the multi-layered system of intellectual property protections.

When Professor Epstein looks at intellectual property, he is struck by the "structural unity" with real property. ${ }^{151} \mathrm{He}$ sees exclusivity and the right to transfer as the foundations undergirding both systems, while discounting the problems of fragmentation and concentration in both domains. His limited perspective exaggerates the "unity" of real and intellectual property with regard to exclusivity and freedom to transfer while overlooking the many structural differences that distinguish real and intellectual property.

There is little doubt that intellectual property rights can be exclusive. But they need not be and often are not, at least not to the extent associated with real property. Property rights enthusiasts no doubt find some solace in the clause empowering Congress to enact patent and copyright laws. The U.S. Constitution refers to "securing for limited

148. See generally Roberta Rosenthal Kwall, Copyright and the Moral Right: Is an American Marriage Possible?, 38 VAND. L. REV. 1 (1985); Roberta Rosenthal Kwall, How Fine Art Fates Post VARA, 1 MARQ. InTELl. Prop. L. Rev. 1 (1997).

149. See 17 U.S.C. $\S 106 \mathrm{~A}(\mathrm{e})(1)$ (2006) (barring transfer of moral rights, but allowing waiver); Neil Netanel, Alienability Restrictions and the Enhancement of Author Autonomy in United States and Continental Copyright Law, 12 CARDOZO ARTS \& ENT. L.J. 1 (1994); Neal Netanel, Copyright Alienability Restrictions and the Enhancement of Author Autonomy: $A$ Normative Evaluation, 24 RUTGERS L.J. 347 (1993).

150. See 17 U.S.C. § 106A(a)(3)(B).

151. See Epstein, Structural Unity, supra note 22. 
Times to Authors and Inventors the exclusive Right to their respective Writings and Discoveries" as a means "To promote the Progress of Science and useful Arts."152 But the utilitarian purpose of this clause, as well as the manner in which Congress and the courts have effectuated this purpose, belies Professor Epstein's equation of exclusive real property rights and exclusive intellectual property rights.

Exclusivity in the realm of real property addresses the "tragedy of the commons." 153 Providing exclusive rights to land and other tangible resources limits the overuse of inherently depletable resources. By contrast, intellectual resources (knowledge) are not depletable and hence are not subject to overuse externalities. ${ }^{154}$ Treating them as real property can lead to underutilization. We can all enjoy a Mozart opera without diminishing the enjoyment of others, whereas we could not all productively graze our herds on a given acre of land or enjoy a particular chocolate ice cream cone without adversely affecting the use and enjoyment of others. Intellectual property protections use the provision of rights (of varying degrees of exclusivity) to promote technological innovation and expressive creativity. But as noted earlier, progress in technology and the arts is a cumulative process in ways that development of land is not. Intellectual property laws seek to balance the interests of pioneering innovators and subsequent improvers in the pursuit of progress.

Exclusive rights of the character associated with real property would stand in the way of technological and expressive progress in many areas of creativity. ${ }^{155}$ Thus, Congress has not declared the first inventor the fee simple absolute owner of their intellectual creativity. To do so would violate the Constitution's "limited times" condition. ${ }^{156}$ But putting this attenuated constraint aside, ${ }^{157}$ Congress has limited the duration and the rights of intellectual property owners in significant respects to achieve an appropriate balance between incentives to create and opportunities for later improvers.

Patent rights tend toward the more exclusive end of the control spectrum, although the relatively short duration of patent protection (twenty years from the filing of an application) and the ability for subsequent inventors to patent improvements (although they will need to license underlying patented inventions in order to practice their

152. U.S. CONST. art. I, $\S 8$, cl. 8 .

153. See Hardin, supra note 68; POSNER, supra note 70.

154. See Stewart Sterk, Intellectualizing Property: The Tenuous Connections Between Land and Copyright, 83 WASH. U. L.Q. 417 (2005).

155. See Merges \& Nelson, supra note 85.

156. See U.S. CONST. art. I, $\S 8$, cl. 8 .

157. See Eldred v. Ashcroft, 537 U.S. 186 (2003). 
improvements) temper such strength. ${ }^{158}$ Copyright law takes a more varied approach to exclusivity. At the most basic level, copyright law allows independent creation of copyrighted works. ${ }^{159}$ The statute includes numerous exceptions, compulsory licenses, and other limitations on copyright owners' rights in the service of cumulative creativity and other social ends. ${ }^{160}$ Trademark law goes further yet, allowing a broad range of uses of valid trademarks by news organizations as well as competitors (comparative advertising) and parodists. ${ }^{161}$ Trade secret law does not prohibit reverse engineering or independent creation of information protected as trade secrets. ${ }^{162}$

Courts have long recognized inherent limits on exclusivity of intellectual property rights. In the early nineteenth century, Justice Story wove the doctrines of experimental use and fair use into the patent and copyright regimes. ${ }^{163}$ Jurists since that time have embellished upon these doctrines in the pursuit of the appropriate balance between protection and unauthorized use. ${ }^{164}$ It is a substantial exaggeration to suggest that "exclusivity" of rights in the intellectual property context mirrors that concept in the real property context.

The transferability of intellectual property rights also diverges from the real property model in significant respects. The patent and copyright misuse doctrines, for example, limit the freedom of intellectual property owners to leverage their rights into other markets or to inhibit innovation. ${ }^{165}$ Trademark law imposes substantial restrictions on assignment and licensing. ${ }^{166}$ Antitrust law plays a much greater role in policing intellectual property licensing than in real property transactions. ${ }^{167}$

Beyond exclusivity and transferability, the structures of real and intellectual property differ markedly along several other critical dimensions. The PRM generally believes that most if not all tangible resources should be owned. Yet intellectual property law tends to operate from the opposite default - market failure justifies intellectual property protection. Patent law excludes protection for abstract concepts and

158. See Robert P. Merges, Intellectual Property Rights and Bargaining Breakdown: The Case of Blocking Patents, 62 TENN. L. REV. 75 (1994).

159. See Sheldon v. Metro-Goldwyn Pictures Corp., 81 F.2d 49, 54 (2d Cir. 1936).

160. See IPNTA, supra note 51, at 483-84, 500-02.

161. See id. at 803-13.

162. See id. at 74-79.

163. See Folsom v. Marsh, 9 F. Cas. 342 (C.C.D. Mass. 1841) (No. 4901); Whittemore v. Cutter, 29 F. Cas. 1120 (C.C.D. Mass. 1813) (No. 17,600).

164. See IPNTA, supra note 51, at 308-12, 506-50.

165. See id. at 308-30 (patent misuse), 552 (copyright misuse).

166. See id. at 798-803 (describing doctrines barring assignments in gross and naked licenses).

167. See id. at 1097-190. 
scientific principles. ${ }^{168}$ Copyright law does not extend to unoriginal compilations, even when they require substantial effort. ${ }^{169}$ Patent and copyright aspire for knowledge to be unowned-in the public domainafter their term has expired. The same cannot be said for tangible property systems.

A further structural difference between real and intellectual property relates to the nature of boundaries and the implications for transaction costs. Whereas tangible property can usually be defined with reasonable clarity and can be verified at relatively low cost, various types of intellectual property have notoriously fuzzy boundaries. ${ }^{170}$ Such boundary definition problems, and the due diligence, transaction, and dispute resolution costs that they entail, raise serious questions about the desirability of some types of intellectual property.

Real and intellectual property differ significantly in terms of enforcement costs. Whereas land and other forms of tangible property can be enclosed and monitored, the flow of knowledge is particularly difficult to observe. For this reason, trade secrets are notoriously difficult to protect. Digital technology and the Internet have made the products of traditional content industries-sound recordings, sheet music, moviesmuch more vulnerable to unauthorized distribution. Professor Epstein's equation of real and intellectual property skates over these significant differences.

\section{Personality Disorders}

Psychological difficulties can strain any relationship. The problem is compounded when both partners confront internal tensions. Such challenges pose a substantial obstacle to the PRM-IP union.

Libertarianism exhibits profound schizophrenia with regard to the concept of intellectual property. Whereas Professor Epstein sees nearly

168. See Diamond v. Diehr, 450 U.S. 175, 185 (1981) ("This Court has undoubtedly recognized limits to $\S 101$ and every discovery is not embraced within the statutory terms. Excluded from such patent protection are laws of nature, natural phenomena, and abstract ideas."); Parker v. Flook, 437 U.S. 584 (1978); Gottschalk v. Benson, 409 U.S. 63,67 (1972) ("[p]henomena of nature, though just discovered, mental processes, and abstract intellectual concepts are ... the basic tools of scientific and technological work"); Funk Brothers Seed Co. v. Kalo Inoculant Co., 333 U.S. 127, 130 (1948) (fundamental scientific principles as "part of the storehouse of knowledge" and manifestations of laws of nature as "free to all men and reserved exclusively to none"); Mackay Radio \& Tel. Co. v. Radio Corp. of Am., 306 U.S. 86, 94 (1939) ("a scientific truth, or the mathematical expression of it, is not patentable invention"); O'Reilly v. Morse, 56 U.S. (15 How.) 62 (1854); see also Kewanee Oil Co. v. Bicron Corp., 416 U.S. 470, 483 (1974) ("Since no patent is available for a discovery, however useful, novel, and nonobvious, unless it falls within one of the express categories of patentable subject matter of 35 U.S.C. $\$ 101$, the holder of such a discovery would have no reason to apply for a patent whether trade secret protection existed or not.").

169. See Feist Publ'ns Inc. v. Rural Tel. Serv. Co., 499 U.S. 340 (1991).

170. See Bessen \& Meurer, supra note 94. 
every resource-whether tangible or intangible - as property that should be protected by exclusive rights, many libertarians have serious reservations about extrapolating property rights in tangible resources to the realm of intangibles. Freidrich von Hayek, perhaps the most influential libertarian theorist of the twentieth century, raised serious doubts about the equation of tangible and intangible resources:

The difference between [copyrights and patents] and other kinds of property rights is this: while ownership of material goods guides the use of scarce means to their most important uses, in the case of immaterial goods such as literary productions and technological inventions the ability to produce them is also limited, yet once they have come into existence, they can be indefinitely multiplied and can be made scarce only by law in order to create an inducement to produce such ideas. Yet it is not obvious that such forced scarcity is the most effective way to stimulate the human creative process. ${ }^{171}$

Along these lines, several libertarian theorists see scarcity, and not the act of creation, as the fundamental justification for property rights. ${ }^{172}$ They view the recognition of property-type rights in intellectual creativity as inhibiting the freedom of others to use tangible resources and to engage in free expression. ${ }^{173}$ As Palmer notes, "[m]onopoly privilege and censorship lie at the historical root of patent and copyright." "Th4 These scholars worry that intellectual property potentially impedes the process of creative destruction ${ }^{175}$ that moves society forward.

The concern over such freedom took root within the computer programming field in the 1980s. Prior to that time, computer programmers enjoyed largely unfettered freedom to use and adapt computer code. Competitive pressures, however, led computer vendors to assert greater control over the use of software. Such restrictions spurred Richard Stallman, a researcher in the Artificial Intelligence Laboratory at the Massachusetts Institute of Technology, to develop a technical and

171. See Freidrich A. von Hayek, The Fatal Conceit: THE ERrors of Socialism 36 (1988); see also ARNOLd PLANT, THE ECONOMIC THEORY CONCERNING PATENTS FOR INVENTIONS 26 (1934).

172. Such scholars interpret Locke as justifying property not on the basis of rewarding labor but instead on the basis of occupancy (or possession) of resources. See N. Stephan Kinsella, Against Intellectual Property, 15 J. LiBERTARIAN STUD. 1, 27-28 (2001).

173. See id.; Roderick T. Long, The Libertarian Case Against Intellectual Property Rights, FORMUlations, Autumn 1995, available at http:/libertariannation.org/a/f31l1.html; Tom G. Palmer, Are Patents and Copyrights Morally Justified? The Philosophy of Property Rights and Ideal Objects, 13 HARV. J.L. \& PUB. POL'Y 818 (1990); Tom G. Palmer, Intellectual Property: A Non-Posnerian Law and Economics Approach, 12 HAMLINE L. REV. 261 (1989); Jesse Walker, Copy Catfight: How Intellectual Property Laws Stifle Popular Culture, ReASON, Mar. 2000, available at http://www.reason.com/news/ show/27635.html.

174. Palmer, Intellectual Property: A Non-Posnerian Law and Economics Approach, supra note 173 , at 264 .

175. See JosePH SCHUMPETER, CAPITALiSM, SOCIALISM AND DEMOCRACY (3d ed. 1950). 
legal strategy aimed at restoring freedom to use and adapt computer code. ${ }^{176}$ This effort grew into the open source movement, a collaborative production and design framework that eschews proprietary restrictions on innovation. ${ }^{177}$

Over the past decade, a phalanx of "cyberlibertarians" has questioned the role of intellectual property in cyberspace. In 1996, John Perry Barlow proclaimed "A Declaration of the Independence of Cyberspace":

Governments of the Industrial World, you weary giants of flesh and steel, I come from Cyberspace, the new home of Mind. On behalf of the future, I ask you of the past to leave us alone. You are not welcome among us. You have no sovereignty where we gather. ..

Your increasingly obsolete information industries would perpetuate themselves by proposing laws, in America and elsewhere, that claim to own speech itself throughout the world. These laws would declare ideas to be another industrial product, no more noble than pig iron. In our world, whatever the human mind may create can be reproduced and distributed infinitely at no cost. The global conveyance of thought no longer requires your factories to accomplish.

These increasingly hostile and colonial measures place us in the same position as those previous lovers of freedom and self-determination who had to reject the authorities of distant, uninformed powers. . . ${ }^{178}$

Various other organizations asserting libertarian mottos see intellectual property as a threat to basic freedoms. ${ }^{179}$

Thus, libertarians are deeply divided on whether and in what circumstances intellectual property recognition is justified. Professor Epstein cannot claim the whole libertarian mantle on such questions. Division within the libertarian camp poses a serious impediment to the PRM-IP relationship.

176. See SAM Williams, FREE AS IN FREEDOM: RICHARD STALlMAN's CRUSADE FOR FREE SOFTWARE (2002); Brian W. Carver, Share and Share Alike: Understanding and Enforcing Open Source and Free Software Licenses, 20 BERKELEY TECH. L.J. 443 (2005).

177. See STEVEN WEBER, THE SUCCESS OF OPEN SOURCE (2004).

178. A Declaration of Independence of Cyberspace, http://homes.eff.org/ barlow/ Declaration-Final.html; see also John Perry Barlow, The Economy of Ideas, WIRED, Mar. 1994, available at http://www.wired.com/wired/archive/2.03/economy.ideas.html (arguing that the freeing of expression from physical embodiment in the digital age makes intellectual property an untenable threat to the freedom of expression); David R. Johnson \& David Post, Law and Borders - The Rise of Law in Cyberspace, 48 STAN. L. REV. 1367 (1996). Such utopian anarchist views of cyberspace are now considered naive. See Julie E. Cohen, Cyberspace as/and Space, 107 COLUM. L. REV. 210, 216-17 (2007) (discussing opposing views).

179. See, e.g., Electronic Frontier Foundation, http://www.eff.org (last visited Apr. 24, 2007) ("Defending Freedom in the Digital World"); Freedom to Tinker, http://freedom-to-tinker.com (last visited Apr. 24, 2007) (asserting "freedom to understand, discuss, repair, and modify the technological devices you own"); The Technology Liberation Front, http://www.techliberation.com/about-tlf.php (last visited Apr. 24, 2007) (seeking to reverse "over-regulation of the Internet"). 
Turning the mirror toward the intellectual property side of the relationship, various personality fissures emerge there as well. The eBay case illustrated some of those divisions. Pharmaceutical companies and patent licensing entities supported the Federal Circuit's strong presumption that permanent injunctions should issue when patent infringement is found, whereas many information technology companies favored the exercise of equitable discretion in fashioning relief. More generally, the divide separating the pharmaceutical and information technology industries had, at least through early 2007 , resulted in a stalemate on patent reform legislation. ${ }^{180}$ Even within the biomedical sector, there is substantial tension between traditional pharmaceutical companies and biotechnology companies on the patenting of genetic sequences. ${ }^{181}$ Pharmaceutical companies worry that patents on sequences could inhibit downstream product research. ${ }^{182}$ Further, the information technology sector is deeply divided on open source software. A growing contingent of information technology companies endorse the open source movement, ${ }^{183}$ while Microsoft seeks to limit its spread. ${ }^{184}$ Content and technology companies bicker over whether digital rights management should be used to protect music distributed over the Internet. ${ }^{185}$

Given the internal issues that both the PRM and intellectual property owners bring to the relationship, Dr. Phil would have his hands full counseling this couple.

180. See Geier, supra note 129 (quoting one observer of the patent reform process as stating that "[a]fter promising beginnings, the strongest provisions, subjected to gamesmanship by big companies - particularly the pharmaceutical industry-have been gutted to render the reform 'much ado about nothing."'); Andrew Noyes, Lobbying; New Group Challenges Tech Industry Patent Consensus, TeCH. DaILy, Feb. 12, 2007; Patti Waldmeir, Reform of Patent Law Seems Probable as Obstacles Clear, FIN. TIMES, Feb. 8, 2007, at World News 9.

181. See Robert P. Merges, $A$ New Dynamism in the Public Domain, 71 U. CHI. L. REV. 183, 186-91 (2004) (describing efforts by the traditional pharmaceutical industry to push genetic sequence information, a core product of biotechnology companies, into the public domain).

182. See Michael A. Heller \& Rebecca S. Eisenberg, Can Patents Deter Innovation? The Anticommons in Biomedical Research, 280 SCI. 698 (1998).

183. See Merges, A New Dynamism, supra note 181, at 191-93 (describing efforts by IBM and some other information technology companies to support open source projects as a way of reducing Microsoft's dominant position).

184. See, e.g., Ingrid Marson, Microsoft: Open Source "Not Reliable or Dependable,"C|Net News.com, May 22, 2006, http://news.com.com/Microsoft+Open+source+not+reliable+ or+dependable/2100-7344_3-6074237.html; Glyn Moody, A Brief History of Microsoft FUD, LXer: Linux News, Mar. 30, 2006, available at http:/lxer.com/module/newswire/view/ 57261/index.html.

185. See Steve Jobs, Thoughts on Music, Feb. 6, 2007, http://www.apple.com/hotnews/ thoughtsonmusic/; $A$ lock on the market; To the music industry's chagrin, Steve Jobs wants labels to allow the copying of downloaded songs, Editorial, L.A. TIMES, Feb. 8, 2007, at A20; Mike Musgrove, Jobs's Music Proposal Rebuffed: Piracy Software Not the Problem, Industry Executive Says, WASH. POST, Feb. 9, 2007, at D2. 


\section{Political Differences}

Even if religious, functional, and psychological challenges can be surmounted, the PRM-IP relationship will undoubtedly face significant political tension. Although true love does on occasion overcome deep political division-as evidenced by the marriage of conservative Republican operative Mary Maitlin and liberal Democratic campaign guru James Carville - differences in politics don't make a relationship any easier, ${ }^{186}$ especially when the relationship is premised on working to achieve particular common political ends. It seems likely that PRM advocates and intellectual property interests would bring different social groups to the relationship. They might not enjoy each other's friends. They could be offended by beliefs of the other and support different causes. In addition, social relationships often play a significant role in developing political alliances. Thus, political differences can be expected to complicate a relationship that is so dependent on ongoing policymaking and judicial appointments.

The PRM traces its roots to and continues to be aligned with deeply conservative, anti-government Republican politicians and political action groups. ${ }^{187}$ Intellectual property owners, by contrast, reflect a much wider range of political stripes. Information technology companies are relatively agnostic regarding political allegiance, ${ }^{188}$ whereas the pharmaceutical industry has been more aligned with the Republican party. ${ }^{189}$ Content industries (Hollywood) have long had close ties with Democratic lawmakers and administrations. ${ }^{190}$ Jack Valenti, long the influential head of the Motion Picture Association of America (MPAA),

186. As noted by one observer: "Though Mary Matlin and James Carville are an exception . . the rule remains that liberals and conservatives probably can't have serious relationships. UPDATE: And if we think it's hard for Republicans and Democrats, just imagine how it is for Libertarians." Alarming News, http://www.alarmingnews.com/archives/003315.html (July 16, 2005, 07:43 PM). At lcast one online dating service sees a market advantage to political screening of prospective partners. See www.DemocratSingles.com (last visited Apr. 24, 2007) ("THE online dating site designed exclusively for Democrats and those who love them.").

187. See Eagle, supra note 62; Kendall \& Lord, supra note 1

188. Communications and electronics companies have slightly favored Democrats. See Opensecrets.org, http://www.opensecrets.org/industries/indus.asp?ind=B\&cycle=2006 (last visited Apr. 24, 2007) (showing that communications and electronics companies have given 56 percent of their political campaign contributions to Democrats since 1990). Computer and Internet companies have contributed to both parties approximately evenly. See Opensecrets.org, http:/www.opensecrets.org/ industries/indus.asp?Ind=B12 (last visited Apr. 24, 2007).

189. See

Opensecrets.org, http://www.opensecrets.org/industries/indus.asp?cycle=2006\&ind= H4300 (last visited Apr. 24, 2007) (showing that pharmaceutical companies have given 72 percent of their political campaign contributions to Republicans since 1990 , although the distribution between parties has become more even in recent years).

190. See Opensecrets.org, http://www.opensecrets.org/industries/indus.asp?cycle= 2006\&ind=B02 (last visited Apr. 24, 2007) (television, movie, and music industries have provided 68 percent of their political contributions to Democrats since 1990). 
began his public career as a top adviser to President Lyndon Johnson. ${ }^{191}$ The organization maintained closer ties to Democratic lawmakers throughout Valenti's almost four decades at the helm. After Valenti's retirement, the MPAA hired Dan Glickman, a former Democratic congressman and Secretary of Agriculture in the Clinton Administration, to lead the organization, much to the dismay of Republican lawmakers. ${ }^{192}$ Hollywood producers, directors, and actors have long been closer to Democratic politicians and causes - such as the environmental movement. ${ }^{193}$ This clearly would not sit well with Professor Epstein or core PRM members.

The foregoing analysis suggests rocky times ahead for the PRM-IP union. Although they both see "property rights" as key to their future, their conceptions differ markedly. The PRM's absolutist view of property rights contrasts with the much more flexible and pragmatic needs of dynamic and effective intellectual property rights system.

\section{IMPLICATIONS OF THE RISE OF INTELLECTUAL PROPERTY FOR THE PROTECTION OF REAL PROPERTY}

The PRM has two ultimate goals: to press for stronger property rights and less government interference with free markets and individual liberty. Will expanding the "property tent" to include intellectual property promote those goals? Clearly not the latter since intellectual property is a form of government intervention into the operation of the free market. What about the former?

Conceiving of intellectual property and real property in the same frame of reference seems more likely to lead in exactly the opposite direction that the PRM seeks to go-that is, the notion that individual land parcels can be viewed as discrete islands without any ecological or social interdependency that might justify governmental intervention. As ecologists and scholars from Pinchot ${ }^{194}$ to Leopold $^{195}$ to Sax ${ }^{196}$ have

191. Mike Dorning, Film Industry's screenings in D.C. a ticket to access, CHI. TRIB., July 17 , 2006, at CN1; Jim Puzzanghera, Still in the spotlight; After retiring as lobbyist for the major film studios, Jack Valenti continues to live a life of D.C. Royalty, working his connections and attracting attention, Jan. 7, 2007, at C1.

192. See Michael Kinsley, Glickman Rex, WASH. POST, Jul. 11, 2004, at B07 (observing that "some Republicans threatened dire consequences if the MPAA anointed a Democrat"); Judy Sarasohn, Playing a GOP Part for Hollywood, WASH. POST, Nov. 4, 2004, at A23 (reporting the MPAA's decision to hire a Republican activist as the MPAA's Executive Vice President of Global Government and quoting Dan Glickman saying "quite frankly, since I am so actively perceived Democrat, I wanted someone who is an actively perceived Republican in the organization").

193. See Green Hollywood, Variety, http:/www.variety.com/index.asp?layout= evGreenHollywood (last visited Apr. 24, 2007) (featuring the many connections between Hollywood and the environmental movement).

194. See Char Miller, GifFord PINCHOT AND THE MAKING OF MODERN ENVIRONMENTALISM (2001); RODRICK NASH, WILDERNESS AND THE AMERICAN MIND (1967). 
emphasized, however, the interdependency of land and other natural resources cannot be denied and such interdependency justifies a governmental role in resource policy. The case for governmental intervention and collective limitations on land and resource use expands with the pressures of population density and resource use, collective interests in resource management and stewardship, and the accretion of scientific knowledge about human impacts on ecosystems. Bringing intellectual property into the "property tent" will likely complement the interdependency conception of resources.

Several characteristics of intellectual resources and the nature of innovation bear this out. First, the cumulative nature of innovation means that almost all innovations are linked to other innovations to some degree. Inventors today "stand on the shoulders of giants" in pushing the frontiers of science and technology. A similar phenomenon connects expressive creativity. Authors, artists, and musicians build on and respond to the creativity of those who came before. Therefore, intellectual property policy correctly resists the conception of intellectual resources as discrete and insular. Intellectual resources are inherently interdependent. In this way, intellectual resources come closer to the Leopoldian conception of the land resource as being a web of interrelated elements than it does to the PRM conception of every parcel as an island. Granting strong, exclusive rights to inventors and authors rests on unrealistic optimism about transaction costs. Coasean bargaining is unlikely to provide the optimal usage and advance of knowledge in all circumstances. That is not to say that property rights have no role to play in promoting progress. They play an essential role, but care must be taken to tailor the scope of protection, rights, and remedies to particular creative contexts. Dogmatic belief in the most extensive bundle of property rights overlooks much of the challenge of spurring technological and expressive creativity.

Second, the optimal system for promoting creativity changes with society and technology. The optimal system for promoting traditional pharmaceutical innovation might not be appropriate for genomic research. Similarly, the appropriate balance for copyright protection in the era of mechanical reproduction of works of authorship might not be optimal for the digital age. Further, the digital age will continue to evolve, requiring adjustments in the intellectual property system. The need for legal rules and institutions to adapt to such dynamism will push against the PRM's static conception of property rights. The need to evolve

195. See Aldo Leopold, The Land Ethic, in A SAND CoUNTY ALMANAC (1949).

196. See Joseph L. Sax, Property Rights and the Economy of Nature: Understanding Lucas v. South Carolina Coastal Council, 45 STAN. L. REV. 1433 (1993); Joseph L. Sax, Some Thoughts on the Decline of Private Property, 58 WASH. L. REV. 481 (1983). 
intellectual property systems could be hampered by an overly restrictive interpretation of the Takings Clause.

Third, the trend of digital technology toward greater collaborative creativity and costly enforcement seems unlikely to support traditional conceptions of ownership and control. A growing number of successful business models on the Internet downplay proprietary rights and use ancillary methods for deriving revenue. We increasingly see open source development of infrastructure, advertising-supported content and services, and keyword advertising. The debate of "network neutrality"197 parallels debates over public provision of highways and other resources. ${ }^{198}$ Due to the inherent nature of network resources, the PRM will face an increasingly uphill battle trying to colonize cyberspace. Other economic models will undoubtedly play a major role in this domain.

Thus, the emergence of intellectual property seems unlikely to support the PRM's core agenda. Intellectual property has never fit the real property mold particularly well and the inherent attributes of intellectual resources as well as the increasingly interdependent nature of information ecosystems points away from the PRM's conception of property. By expanding the property tent to encompass intellectual property, property rights enthusiasts run the risk of diluting the distinctive attributes of real property that brought it special attention at the founding of the nation. Such a conception has been on the decline and the growing importance of intellectual property seems likely to hasten that trend. As Justice Benjamin Cardozo remarked in describing the development of water rights in the American West, "[h]ere we have the conscious departure from a known rule, and the deliberate adoption of a new one, in obedience to the promptings of a social need so obvious and so insistent as to overrun the ancient channel and cut a new one for itself." ${ }^{199}$ The rise of intellectual property, like water resources, highlights both the complexity and interdependence of resources in modern societies. Efforts to shoehorn legal protection for such resources into the real property mold will undoubtedly fail and may well hasten the demise of the rigid conception of private property rights.

\section{CONCLUSION}

Upon reflection, the Property Rights Movement is too limited and grounded in absolutist ideology to support the needs of a dynamic, resource-sensitive intellectual property system. Professor Epstein's

197. See Tim Wu, Network Neutrality, Broadband Discrimination, 2 J. TELECOMM. \& HiGH TECH. L. 141 (2003); Kai Zhu, Bringing Neutrality to Network Neutrality, 21 BERKELEY TECH. L.J. (forthcoming 2007).

198. See Rose, supra note 71 , at 723-25.

199. See Benjamin Cardozo, The Growth of THE LAW 119-20 (1924). 
simplistic equation of real and intellectual property generates more heat than light. It is not particularly helpful to think of real and intellectual property as structurally unified. The differences matter significantly and resorting to rhetorical metaphors distracts attention from critical issues. As Judge (later Justice) Cardozo cautioned in 1926, "[m]etaphors in law are to be narrowly watched, for starting as devices to liberate thought, they end often by enslaving it." 200

This is not to say that property rights enthusiasts and some intellectual property owners will not date on occasion. Just as in the eBay case, various intellectual property owners will from time to time press for strong protection, and they are prone to being seduced by libertarian impulses. But the PRM will want more than even these owners are willing to stomach. In the end, deeply ingrained religious, functional, psychological, and political differences stand in the way of a harmonious and sustainable marriage.

200. See Berkey v. Third Ave. Ry. Co., 155 N.E. 58, 61 (N.Y. 1926). 